Article

\title{
Framing Muslims in the "War on Terror": Representations of Ideological Violence by Muslim versus Non-Muslim Perpetrators in Canadian National News Media
}

\author{
Azeezah Kanji \\ Noor Cultural Centre, Toronto, ON M3C 1K1, Canada; azeezah.kanji@utoronto.ca \\ Received: 9 August 2018; Accepted: 10 September 2018; Published: 12 September 2018
}

\begin{abstract}
This study compared representations of ideological violence by Muslim versus non-Muslim perpetrators in Canadian national news media (the Globe and Mail, National Post, and CBC). Both quantitative and qualitative disparities were examined. Acts of Muslim violence received 1.5 times more coverage, on average, than non-Muslim ones, and thwarted Muslim plots received five times more coverage. Muslim incidents were more likely to be labelled "terrorism" and linked to other episodes of violence, and Muslim perpetrators were more likely to be labelled by their religious and ethno-racial identities. These patterns in representation serve to stabilise the racial formations of the Canadian national security state in the "war on terror".
\end{abstract}

Keywords: Islamophobia; terrorism; Canadian news media; framing

\section{Introduction}

"The media in the modern era are indisputably an instrument of war," writes Kenneth Payne (Payne 2005, p. 81) —one wielded with potent effect in the current era of the "war on terror." ${ }^{1}$ Multiple analyses have examined how media representations of Muslim difference and dangerousness are constitutive in shaping notions of Canadian national identity, and Western civilizational identity more broadly, against an Orientalised enemy Other (Bullock and Jafri 2000; Jiwani 2005a, 2005b; Marin 2011; Thobani 2003; Ismael and Measor 2003; Jiwani 2004; Poynting and Perry 2007; Belkhodja and Richard 2006; Jiwani and Dessner 2016; Olwan 2013; Meer et al. 2010; Moore et al. 2008; Kumar 2012). Here, I consider how the figure of the Muslim "terrorist" has been constructed in Canadian national news media, and how it has been imbued with an aura of exceptional menace, by conducting a comparative analysis of representations of ideological violence committed by Muslim versus non-Muslim perpetrators. I look at both quantitative disparities in the amounts of coverage received by incidents with Muslim versus non-Muslim perpetrators, and qualitative disparities in the framing of incidents (for example, whether the label "terrorism" is applied, or whether the ethnic and religious identities of the perpetrator are specified).

Previous studies have discerned quantitative as well as qualitative discrepancies in the coverage of political and ideological violence in North America, with Muslim incidents receiving consistently disproportionate levels of negative attention. Erin Kearns, Allison Betus, and Anthony Lemieux's 2017 analysis of American news media determined that attacks by Muslim perpetrators in the United States received, on average, 449\% more coverage in American media than other attacks. The 2013 Boston

1 While the nomenclature of a "war on terror" has been officially abandoned, the practice of a global "war on terror" persists—and indeed, has been steadily expanded in geographic scope since 2001. 
Marathon bombing (which killed three people, other than the attacker), for instance, garnered five times more coverage than Wade Michael Page's 2012 attack on a Sikh gurdwara in Wisconsin (which killed six), and more than two-and-a-half times more coverage than Dylann Roof's 2016 shooting in a Black Church in Charleston (which killed nine) (Kearns et al., forthcoming). The Institute for Social Policy and Understanding similarly found that completed acts of violence by Muslim perpetrators received twice as much coverage in the New York Times and the Washington Post as analogous acts by non-Muslims, and that thwarted Muslim plots attracted seven-and-a-half times the coverage of non-Muslim plots (Institute for Social Policy and Understanding 2018). Regarding Canadian incidents, American media watchdog organization Fairness and Accuracy in Reporting (FAIR) found that the 2017 Quebec mosque shooting received six times less coverage in American media than the 2014 Parliament Hill attack by Michael Zehaf-Bibeau, a convert to Islam, even though the mosque shooting involved six times more deaths (Naureckas 2017). The disparities in volume of coverage also pertain to other types of violence racialised as Muslim phenomena: Yasmin Jiwani's survey of the Canadian national newspaper the Globe and Mail identified 66 articles on the Shafia femicide case alone (which was widely represented as an "honour killing" rooted in the perpetrators' Afghan and Muslim culture), but only 59 on the "murder of women and domestic violence" in general from 2005 to 2012 (Jiwani 2014; Shier and Shor 2016).

Several studies have also analyzed the distinct features of media frames applied to contextualise and explain violence committed by Muslims, which serve to associate terrorism with Islam and project the terrorist threat onto a collectivised Muslim Others have expelled from the aegis of national belonging-legitimizing and naturalizing state violence against Muslims in the claimed service of counter-terrorism (Karim 2002; Ahmed and Matthes 2016; Poole 2011, 2018; Smolash 2009; Odartey-Wellington 2009). As Robert Entman has explicated, "To frame is to select some aspects of a perceived reality and make them more salient in a communicating text, in such a way as to promote a particular problem definition, causal interpretation, moral evaluation, and/or treatment recommendation for the item described" (Entman 1993, p. 52). The boundaries of the frame determine which aspects of reality are included and which are excluded, defining the terms and limits of public debate. Framing, therefore, is "an exercise in power" (Lewis and Reese 2009, p. 86) in two ways: frames emerge from dominant configurations of power, and are influential in structuring the use of political power to address the issue being framed. "The use of the terrorism frame serves several functions," observe Pippa Norris, Montague Kern, and Marion Just, "both cognitive, by linking together disparate facts, events, and leaders, and also evaluative, by naming perpetrators, identifying victims, and attributing blame [ ... ] reshaping perceptions of 'friends' and 'enemies'" (Norris et al. 2003, p. 15).

Kimberly Powell's analysis of coverage of terrorism events in mainstream national American print and digital news media found that "terrorism is framed primarily as a problem from Islam, with domestic terrorism being treated as less threatening" (Powell 2011, p. 95) Muslim perpetrators of violence were more likely to be defined as "terrorists," labeled using their religious identity, represented as having more violent motives, and linked in media reports to larger terror networks such as Al-Qaeda—even before motive had been authoritatively established. The threat represented by non-Muslim perpetrators, in contrast, was individualised-for example, through the ascription of non-Muslim "homegrown" violence to mental instability: "[ $t]$ he act is determined to be a lone act of a troubled individual versus part of the actions of a terror cell, thus, it is not a future threat to safety in the United States" (Powell 2011, p. 106). The Institute for Social Policy and Understanding's study confirmed Powell's findings that media reports on acts of ideological violence committed by Muslims were more likely to employ the terms "terrorist" /"terrorism" and "extremism," and to specify the perpetrator's religious identity (Institute for Social Policy and Understanding 2018). Inversely, Smeeta Mishra's analysis of the New York Times noted that Muslim men were primarily covered in relation to topics such as terrorism, militancy, and illegal immigration, "establish[ing] them as fanatics who needed to be controlled" (Mishra 2007). 
With respect to Canadian news media, John Miller and Cybele Sack's study of the treatment of the "Toronto 18 " terrorism plot in Toronto newspapers documented significant shortcomings that served to reproduce the state's securitizing narrative; they concluded that "a significant portion of the published commentary raised unreasonable public alarm, cast suspicion on the followers of a major religion and impugned Islam itself, failed to subject the allegations of the Canadian government and security officials to rigorous scrutiny, and predicted guilt before the suspects were able to exercise their democratic rights to a fair trial" (and in the event, charges against seven of the 18 accused were dropped or stayed) (Miller and Sack 2010, p. 279; Kowalski 2013). Miller and Sack also found that news media coverage of the "Toronto 18 " was far more likely to mention successful acts of "terrorism" committed in other parts of the world, rather than any of the numerous instances of severe rights abuses based on mistaken suspicions by Canadian national security agencies (Miller and Sack n.d.)—salient examples include the arrest and deportation of 24 South Asian immigrants based on unfounded allegations of terrorism in Project Thread, and the secret imprisonment and torture of Maher Arar in Syria with Canadian complicity-promoting the perspective that Muslim "terrorism" constitutes a greater danger than state violence that is executed in the name of counter-terrorism.

In his critique of Canadian news coverage of the "Toronto 18," veteran journalist Robert Fisk observed that the accused (all Muslims of South Asian or Arab ethnicity) were repeatedly referred to as "Canadian-born" rather than "Canadian," effecting a rhetorical banishment from Canadian citizenship (Fisk 2006; Smolash 2009). The symbolic "casting out" (Razack 2007) of Muslims has not been limited to the ambit of citizenship, but extends to the realm of humanity itself: Steuter and Wills' exegesis of coverage of the wars in Afghanistan and Iraq revealed "a pattern of dehumanizing language applied to enemy leaders as well as Arab and Muslim citizens at large" (Steuter and Wills 2009b, p. 7). This pattern was characterised by the prevalence of figurative language likening Muslims and Arabs to "animals, insects and diseases, reinforcing the broader political discourse of essential, hostile difference and, more gravely, potentially laying the groundwork for the language of eradication and annihilation that is the logical corollary to metaphors of the enemy as vermin or virus" (Steuter and Wills 2009a; 2009b, p. 9).

Despite the wealth of literature critiquing Orientalizing and Islamophobic representations of Muslims in Western media, however, there is scant research that directly and systematically compares the coverage of ideology-linked violence committed by Muslim perpetrators versus non-Muslim perpetrators-and no such previous analysis exists for the Canadian context. This is a necessary exercise for identifying the specific practices of representation that perpetuate the stereotypical association of Muslims with terrorism, while rendering far more pervasive sources of violence relatively invisible and marginal in public discourse. This paper-which examines quantitative and qualitative disparities in national Canadian news media coverage of acts of violence committed by Muslims, as compared to violence committed by White supremacists and right-wing extremists-is a contribution towards filling this lacuna.

\section{Methodology}

Incidents of ideological violence for inclusion (listed and described in Table 1) were identified using Craig Forcese's compilation of post-9/11 terrorism prosecutions in Canada (Forcese 2016); the Canadian Incident Database developed by the Canadian Network for Research on Terrorism, Security, and Society, which provides a listing of "terrorism and extremist crime incidents with a Canadian connection" from 1960 to 2015 (Canadian Network for Research on Terrorism, Security and Society n.d.); and news media reports on violent events or plots indicating a connection to political, religious, or ideological motives (incidents were identified by searching for reports on events or plots including the terms "Islamist," "Al-Qaeda," "ISIS," "extreme right-wing" / "right-wing extremist," "neo-Nazi," "White supremacy" / "White supremacist," and "incel" /"involuntarily celibate").

Incidents were limited to those with targets within Canadian territory, occurring between 11 September 2001 (that is, since the onset of the American-led "war on terror") and July 2018, 
and with some reported link to political, religious, or ideological motive (a constitutive component of the definition of "terrorism" in Canadian criminal law). The five incidents in each category (Muslim perpetrators and non-Muslim perpetrators) that received the most coverage in the three media outlets examined were included for analysis; this limitation was imposed to correct for the fact that inchoate acts (such as plots, material support, or other preparations for violence) were more likely to be prosecuted and receive media coverage when the perpetrators were Muslim (see discussion below), skewing the number and nature of discrete identifiable incidents for each category. The incidents covered include all of the fatal ideology-linked acts of violence that have occurred in Canada within the study's time period (two by Muslim perpetrators and four by non-Muslims), as well as several thwarted plots.

Analysis focused on coverage in Canada's two national newspapers-the Globe and Mail (often described as representing a centrist political position), and the National Post (frequently understood as a more right-wing publication) — and Canada's state-funded national broadcaster, the Canadian Broadcasting Corporation (CBC). Media items about each incident were located by searching the media platforms' websites, as well as online databases ProQuest and LexisNexis; searches for each incident were conducted using the names of the perpetrators, the names of the victims, and factual descriptions of the event (for example, "Via Rail plot" or "Toronto van attack"), to locate all relevant coverage. All news and opinion pieces with a substantive reference to the incident in question-that is, that included some description or information of the event-were included. Newswire articles published in more than one outlet were only counted once.

Items were checked for several features: (1) whether the incident was labelled "terrorism"; (2) whether the term "terrorism" was mentioned in the headline (indicating that the story was framed as one about terrorism); (3) whether any political, religious, or ideological affiliation was identified as a motive for the incident (religious and ideological identification were tracked separately for non-Muslim perpetrators, but together for Muslim ones, since the motivating ideology for Muslim perpetrators was represented as emanating from their religious identity - that is, Islam was depicted simultaneously as religion and ideology; see discussion below); (4) whether the ethno-racial identity or the immigration status of the perpetrator was noted; (5) whether other violent incidents were mentioned, in a way that represented the particular event as part of a broader pattern; and (6) whether the mental health or ability of the perpetrator was portrayed as an explanatory factor.

\section{Results}

The quantitative results of the comparative survey are summarized in Tables 2 and 3, below (Table 2 presents the results for each incident, while Table 3 displays overall results for the categories of Muslim perpetrators and non-Muslim perpetrators).

Incidents with Muslim perpetrators received, on average, 1.5 times as much coverage as incidents with non-Muslim perpetrators. Muslim violence and plots were 23 times more likely to be labelled terrorism than non-Muslim violence and plots. Coverage of incidents with Muslim perpetrators was three times more likely to refer to the perpetrator's religious, political, or ideological motive; 8.5 times more likely to specify the perpetrator's ethno-racial identity and/or immigration status; twice as likely to mention other incidents of violence; and twice as likely to discuss the mental health of the perpetrator. 
Table 1. Incidents.

\begin{tabular}{|c|c|c|c|c|c|c|}
\hline \multicolumn{7}{|c|}{ Muslim Perpetrators } \\
\hline Incident & Year & Perpetrators & $\begin{array}{c}\text { Reported Ideological } \\
\text { Affiliation }\end{array}$ & $\begin{array}{c}\text { Deaths (Excluding } \\
\text { Perpetrator) }\end{array}$ & $\begin{array}{l}\text { Labelled Terrorism } \\
\text { by Government }\end{array}$ & Charged as Terrorism \\
\hline “Toronto 18” Plot (thwarted) & 2006 & $\begin{array}{l}\text { Fahim Ahmad, Zakaria Amara, Shareef } \\
\text { Abdelhaleem, Saad Khalid, Saad Gaya, } \\
\text { Amin Durrani, Jahmaal James, Steven } \\
\text { Chand, Ali Dirie, Asad Ansari, } \\
\text { Nishanthan Yogakrishnan (charges } \\
\text { stayed against Qayyum Abdul Jamal, } \\
\text { Yasim Abdi Mohamed, Ahmad Ghany, } \\
\text { Ibrahim Aboud, three unnamed youths) }\end{array}$ & Al-Qaeda & 0 & Yes & Yes \\
\hline Via Rail Plot (thwarted) & 2013 & Raed Jaser, Chiheb Esseghaier & Al-Qaeda & 0 & Yes & Yes \\
\hline $\begin{array}{c}\text { Saint Jean-Sur Richelieu } \\
\text { Attack }\end{array}$ & 2014 & Martin Couture-Rouleau & ISIS & 1 & Yes & N/A (perpetrator killed) \\
\hline Parliament Hill Attack & 2014 & Michael Zehaf-Bibeau & ISIS & 1 & Yes & N/A (perpetrator killed) \\
\hline Edmonton Truck Attack & 2017 & Abdulahi Hasan Sharif & ISIS & 0 & Yes & No \\
\hline Total Deaths & & & & 2 & & \\
\hline \multicolumn{7}{|c|}{ Non-Muslim Perpetrators } \\
\hline Incident & Year & Perpetrators & $\begin{array}{c}\text { Reported Ideological } \\
\text { Affiliation }\end{array}$ & $\begin{array}{l}\text { Deaths (Excluding } \\
\text { Perpetrator) }\end{array}$ & $\begin{array}{l}\text { Labelled Terrorism } \\
\text { by Government }\end{array}$ & Charged as Terrorism \\
\hline White Boy Posse Murders & 2012 & $\begin{array}{c}\text { Randy O'Hagan, Nikolas Nowytzkyj, } \\
\text { Kyle Halbauer, Joshau Petrin }\end{array}$ & White supremacy & 3 & No & No \\
\hline Moncton RCMP Shooting & 2014 & Justin Bourque & $\begin{array}{l}\text { Extreme right-wing, } \\
\text { anti-government }\end{array}$ & 3 & No & No \\
\hline $\begin{array}{l}\text { Halifax Mall Shooting Plot } \\
\text { (thwarted) }\end{array}$ & 2015 & $\begin{array}{l}\text { Lindsay Souvannarath, Randall } \\
\text { Shepherd, James Gamble }\end{array}$ & $\begin{array}{c}\text { Neo-Nazi, } \\
\text { Columbiner }\end{array}$ & 0 & No & No \\
\hline Quebec Mosque Shooting & 2017 & Alexandre Bissonnette & $\begin{array}{l}\text { Extreme right-wing, } \\
\text { anti-Muslim }\end{array}$ & 6 & Yes & No \\
\hline Toronto Van Attack & 2018 & Alek Minassian & $\begin{array}{c}\text { Incel ("involuntarily } \\
\text { celibate") }\end{array}$ & 10 & No & No \\
\hline Total Deaths & & & & 22 & & \\
\hline
\end{tabular}


Table 2. Coverage of Incidents in National News Media.

\begin{tabular}{|c|c|c|c|c|c|c|c|}
\hline \multicolumn{8}{|c|}{ Muslim Perpetrators } \\
\hline Incident & $\begin{array}{l}\text { Number of } \\
\text { Articles }\end{array}$ & $\begin{array}{l}\text { Labelled } \\
\text { Terrorism }\end{array}$ & $\begin{array}{l}\text { Terrorism in } \\
\text { Headline }\end{array}$ & $\begin{array}{l}\text { Political/Religious/Ideological } \\
\text { Affiliation Mentioned }\end{array}$ & $\begin{array}{c}\text { Ethno-Racial } \\
\text { Identity/Immigration } \\
\text { Status Mentioned }\end{array}$ & $\begin{array}{l}\text { Other Violent } \\
\text { Incidents } \\
\text { Mentioned }\end{array}$ & $\begin{array}{c}\text { Mental } \\
\text { Health/Ability } \\
\text { Mentioned }\end{array}$ \\
\hline “Toronto 18" Plot & 437 & $\begin{array}{l}94 \% \\
(411)\end{array}$ & $\begin{array}{l}34 \% \\
(147)\end{array}$ & $\begin{array}{l}61 \% \\
(268)\end{array}$ & $\begin{array}{l}11 \% \\
(50)\end{array}$ & $\begin{array}{l}39 \% \\
(171)\end{array}$ & $\begin{array}{l}0.2 \% \\
(1)\end{array}$ \\
\hline Via Rail Plot & 215 & $\begin{array}{l}96 \% \\
(207)\end{array}$ & $\begin{array}{l}59 \% \\
(127)\end{array}$ & $\begin{array}{l}68 \% \\
(147)\end{array}$ & $\begin{array}{l}46 \% \\
(99)\end{array}$ & $\begin{array}{l}31 \% \\
(67)\end{array}$ & $\begin{array}{l}16 \% \\
(35)\end{array}$ \\
\hline Saint Jean-Sur-Richelieu Attack & 237 & $54 \%$ & $26 \%$ & $\begin{array}{l}71 \% \\
(168)\end{array}$ & $3 \%$ & $83 \%$ & $4 \%$ \\
\hline & & $\begin{array}{l}(129) \\
43 \%\end{array}$ & $12 \%$ & $\begin{array}{l}(168) \\
40 \%\end{array}$ & $\begin{array}{l}(6) \\
5 \%\end{array}$ & $\begin{array}{l}(196) \\
42 \%\end{array}$ & $\begin{array}{l}(10) \\
9 \%\end{array}$ \\
\hline Parliament Hill Attack & 568 & (243) & (68) & (226) & (30) & (239) & (49) \\
\hline Edmonton Truck Attack & 96 & $\begin{array}{l}68 \% \\
(65)\end{array}$ & $\begin{array}{l}29 \% \\
(28)\end{array}$ & $\begin{array}{l}46 \% \\
(44)\end{array}$ & $\begin{array}{l}46 \% \\
(44)\end{array}$ & $\begin{array}{l}29 \% \\
(28)\end{array}$ & $\begin{array}{l}14 \% \\
(13)\end{array}$ \\
\hline Mean & 311 & $71 \%$ & $32 \%$ & $57 \%$ & $22 \%$ & $45 \%$ & $9 \%$ \\
\hline \multicolumn{8}{|c|}{ Non-Muslim Perpetrators } \\
\hline Incident & $\begin{array}{l}\text { Number of } \\
\text { Articles }\end{array}$ & $\begin{array}{l}\text { Labelled } \\
\text { Terrorism }\end{array}$ & $\begin{array}{l}\text { Terrorism in } \\
\text { Headline }\end{array}$ & $\begin{array}{l}\text { Political/Religious/Ideological } \\
\text { Affiliation Mentioned }\end{array}$ & $\begin{array}{c}\text { Ethno-Racial } \\
\text { Identity/Immigration } \\
\text { Status Mentioned }\end{array}$ & $\begin{array}{l}\text { Other Violent } \\
\text { Incidents } \\
\text { Mentioned }\end{array}$ & $\begin{array}{c}\text { Mental } \\
\text { Health/Ability } \\
\text { Mentioned }\end{array}$ \\
\hline White Boy Posse Murders & 29 & $\begin{array}{l}0 \% \\
(0)\end{array}$ & $\begin{array}{l}0 \% \\
(0)\end{array}$ & $\begin{array}{c}\text { Religion } \\
0 \% \\
(0) \\
\text { Ideology } \\
7 \% \\
(2) \\
\end{array}$ & $\begin{array}{l}0 \% \\
(0)\end{array}$ & $\begin{array}{l}3 \% \\
(1)\end{array}$ & $\begin{array}{l}0 \% \\
(0)\end{array}$ \\
\hline Moncton RCMP Shooting & 372 & $\begin{array}{l}1 \% \\
(5)\end{array}$ & $\begin{array}{l}2 \% \\
(7)\end{array}$ & $\begin{array}{c}\text { Religion } \\
3 \% \\
(12) \\
\text { Ideology } \\
9 \% \\
(35) \\
\end{array}$ & $\begin{array}{c}0.5 \% \\
(2)\end{array}$ & $\begin{array}{l}19 \% \\
(70)\end{array}$ & $\begin{array}{l}5 \% \\
(17)\end{array}$ \\
\hline Halifax Mall Shooting Plot & 60 & $\begin{array}{l}0 \% \\
(0)\end{array}$ & $\begin{array}{l}5 \% \\
(3)\end{array}$ & $\begin{array}{c}\text { Religion } \\
3 \% \\
(2) \\
\text { Ideology } \\
25 \% \\
(15) \\
\end{array}$ & $\begin{array}{c}10 \% \\
(6)\end{array}$ & $\begin{array}{l}28 \% \\
(17)\end{array}$ & $\begin{array}{l}5 \% \\
(3)\end{array}$ \\
\hline Quebec Mosque Shooting & 395 & $\begin{array}{l}13 \% \\
(53)\end{array}$ & $\begin{array}{l}4 \% \\
(17)\end{array}$ & $\begin{array}{c}\text { Religion } \\
0.3 \% \\
(1) \\
\text { Ideology } \\
19 \% \\
(76)\end{array}$ & $\begin{array}{l}2 \% \\
(9)\end{array}$ & $\begin{array}{l}29 \% \\
(116)\end{array}$ & $\begin{array}{l}6 \% \\
(23)\end{array}$ \\
\hline
\end{tabular}


Table 2. Cont

\begin{tabular}{|c|c|c|c|c|c|c|c|}
\hline \multicolumn{8}{|c|}{ Non-Muslim Perpetrators } \\
\hline Incident & $\begin{array}{l}\text { Number of } \\
\text { Articles }\end{array}$ & $\begin{array}{l}\text { Labelled } \\
\text { Terrorism }\end{array}$ & $\begin{array}{l}\text { Terrorism in } \\
\text { Headline }\end{array}$ & $\begin{array}{l}\text { Political/Religious/Ideological } \\
\text { Affiliation Mentioned }\end{array}$ & $\begin{array}{c}\text { Ethno-Racial } \\
\text { Identity/Immigration } \\
\text { Status Mentioned }\end{array}$ & $\begin{array}{l}\text { Other Violent } \\
\text { Incidents } \\
\text { Mentioned }\end{array}$ & $\begin{array}{c}\text { Mental } \\
\text { Health/Ability } \\
\text { Mentioned }\end{array}$ \\
\hline Toronto Van Attack & 250 & $\begin{array}{l}1 \% \\
(3)\end{array}$ & $\begin{array}{l}2 \% \\
(6)\end{array}$ & $\begin{array}{c}\text { Religion } \\
0 \% \\
(0) \\
\text { Ideology } \\
23 \% \\
(57) \\
\end{array}$ & $\begin{array}{l}0.4 \% \\
(1)\end{array}$ & $\begin{array}{l}19 \% \\
(47)\end{array}$ & $\begin{array}{l}7 \% \\
(17)\end{array}$ \\
\hline Mean & 221 & $3 \%$ & $3 \%$ & $\begin{array}{c}\text { Religion } \\
1 \% \\
\text { Ideology } \\
17 \%\end{array}$ & $2.6 \%$ & $20 \%$ & $5 \%$ \\
\hline
\end{tabular}

Table 3. Comparison of Coverage-Incidents with Muslim versus Non-Muslim Perpetrators.

\begin{tabular}{ccc}
\hline & Muslim Perpetrators & Non-Muslim Perpetrators \\
\hline Total Deaths & 2 & 22 \\
\hline Mean Number of Articles & 311 & 221 \\
\hline Labelled Terrorism & $71 \%$ & $3 \%$ \\
\hline Terrorism in Headline & $32 \%$ & $3 \%$ \\
\hline Political/Religious/Ideological Motivation Mentioned & $57 \%$ & Religion \\
& & $1 \%$ \\
Ethno-Racial Identity/Immigration Status Mentioned & $17 \%$ & $2.6 \%$ \\
\hline Other Violent Incidents Mentioned & $22 \%$ & $20 \%$ \\
\hline Mental Health/Ability Mentioned & $45 \%$ & $5 \%$ \\
\hline
\end{tabular}




\section{Discussion}

\subsection{Amount of Coverage}

Acts of violence linked to Muslims received, on average, 1.5 times more coverage than those linked to right-wing extremists and White supremacists-despite the fact that the latter produced 11 times more deaths (see Tables 1 and 3). Fatal acts of violence successfully executed by Muslims received, on average, 1.5 times more coverage than those by non-Muslims, while thwarted plots received more than five times more coverage (see Tables 2 and 3). These disparities skew the public perceptions of the spectrum of political violence: while right-wing and White supremacist violence is far more frequent and fatal in Canada (Perry and Scrivens 2015; Monaghan and Molnar 2016), mainstream media conveys the opposite impression. The Parliament Hill and Saint Jean-Sur-Richelieu attacks were overwhelmingly voted by Canadian newsrooms as the "2014 News Story of the Year" —even though Justin Bourque's Moncton mass shooting, which occurred that same year, alone took more lives than both other incidents combined (Cheadle 2014).

It is important to note that data pertaining to the number of media items per incident alone fail to capture the differentials in the intensity of coverage, related to variables such as the placement of stories in the newspaper or prominence in broadcasts, and the images selected to accompany them. For example, other analyses have noted that the Quebec mosque shooting received approximately five minutes of airtime on the CBC's flagship evening news program, The National, the night that it occurred, while the London Borough attacks in the UK five months later were covered with several hours of live reportage and commentary-even though the former occurred in Canada, and both involved approximately the same number of non-perpetrator casualties (six for the Quebec mosque shooting, and eight for the London Borough attacks) (Kanji 2018).

\section{2. "Terrorist" versus "Criminal"}

Violent acts or plots involving Muslim perpetrators were consistently labelled "terrorism" more frequently than those by non-Muslims; overall, Muslim incidents were 23 times more likely to be described as "terrorism" in media reports (see Tables 2 and 3).

This mirrors the racialization of the concept of "terrorism" in official political, bureaucratic, and legal discourse. While the general definition of "terrorism" in the Criminal Code-certain acts of violence to people or property committed "in whole or in part for a political, religious or ideological purpose, objective or cause," with the intention of "intimidating the public [ ... ] or compelling a person, a government or a domestic or an international organization to do or to refrain from doing any act" (s 83.01(1)) - is textually neutral with respect to racial and religious identity, the term effectively functions in state national security discourse as a synonym for violence (or the threat of violence) by Muslims. For instance, the most recent Public Report from the Canadian Security Intelligence Service (CSIS), published in February 2017, included a "Terrorism Timeline" in which all of the listed incidents were committed by Muslims; incidents with non-Muslim perpetrators such as the Quebec mosque and Moncton RCMP shootings were not mentioned at all in the body of the report, despite the fact that both apparently meet the legal definition of "terrorism" as politically-, religiously-, or ideologically-motivated violence (CSIS 2017).

In the wake of the Halifax mall shooting plot, police officials and then-Justice Minister Peter MacKay explained that the plotters - who were reportedly obsessed with neo-Nazi ideology-were better characterised as "murderous misfits" rather than "terrorists" because their attack did not "appear to have been culturally motivated" (CBC News 2015a): indicating that application of the law's terrorism provisions is informed by extra-legal criteria regarding perpetrators' "cultural" identities. Of the two dozen terrorism prosecutions completed under Canada's post-9/11 anti-terrorism law, all but one have been of Muslims or individuals connected to Muslim groups, and all for "inchoate" offences not progressed to violence (such as plots, travelling, and material support) (Forcese and Roach 2015). Similar preparatory activities for violence by right-wing extremist and White supremacist groups-for 
example, paramilitary training exercises by the Three Percenters, a Canadian offshoot of an American extreme-right militia group-have not been treated as criminal offences (Lamoureux 2017).

The designation of certain acts of violence as "terrorism" is significant, because terrorism is represented by political leaders and the judiciary as posing a uniquely existential threat to Canada, rationalizing an exceptionally pre-emptive and punitive response by security agencies and law enforcement. In her genealogy of the concept of "terrorism," Lisa Stampnitzky explicates that "as the problem of terrorism took shape over the course of the 1970s, 1980s, and 1990s, it came to be understood as rooted to a terrorist identity, rather than as a tactic that any group might adopt [ ... ] The identity contains its own explanation: 'terrorists' are evil, irrational actors whose action is driven not by normal interests or political motives but, instead, by their very nature as terrorists" (Stampnitzky 2013, pp. 179-80). As retired justice John Major declared in his report on the Air India bombing, "Terrorism is an existential threat to Canadian society in a way that murder, assault, robbery and other crimes are not. Terrorists reject and challenge the very foundations of Canadian society" (Major 2010, p. 159). Terrorism is understood not only as a crime, but also as an act of war (for example: (Wagstaff 2013)): an offensive on Canada's and the West's proclaimed "civilizational values" of democracy, equality, and freedom. Following the Saint Jean-Sur-Richelieu attack, for instance, the then-Prime Minister Stephen Harper declared it an assault "against not just this soldier and his colleagues but frankly against our very values as a civilised democracy" (Payton 2014). The double-standard in application of the "terrorism" appellation is connected to a deeper paradox: Muslim violence is represented as an existential threat because it is perceived as challenging dominant structures of state and social power-while forms of right-wing violence that are dangerous precisely because they attempt to further entrench the state's status quo structures of White supremacy and patriarchy are not.

Media coverage perpetuated the racialization of terrorism as a predominantly Muslim phenomenon: so that while attacks and plots by Muslims were consistently characterised as "terrorism," an incident such as (non-Muslim) Bourque's shooting spree directed specifically against Royal Canadian Mounted Police (RCMP) officers was not (see Table 2), despite the fact that research indicates that incidents targeting state entities (like police) are more likely to be interpreted as terrorism (Huff and Kertzer 2018). Similarly, Toronto van rampager Alek Minassian, who posted a Facebook message shortly before his attack proclaiming the inauguration of the "incel rebellion"—a reference to "involuntarily celibate" ideology, categorised as a form of "male supremacism" characterized by "a thinly veiled desire for the domination of women and a conviction that the current system oppresses men in favor of women" by the Southern Poverty Law Center (Southern Poverty Law Center 2017) —was only very rarely described as a "terrorist" in media reports (see Table 2). The prevalence of nomenclature such as "Islamic terrorism" and "Islamic extremism"- a welding of religious normativity to violent activity reserved exclusively for Muslim perpetrators, so that perpetrators of other religious backgrounds are not described as "Christian terrorists" or "Judaic extremists," for instance (Karim 2002) - further entrenched the exceptional association of Islam with political violence (a few examples include: (Koring 2006; Freeze 2009; Globe and Mail Editorial Board 2009; Simpson 2014; Kennedy 2014; Selley 2015)). Concomitantly, perpetrators of "terrorism" are depicted not merely as criminals, but also as enemies (for example: (Bourrie 2016; Ivison 2014)). In a piece exhorting Canadians to "know thy enemy," Globe and Mail columnist Christie Blatchford highlighted the obviously-Muslim names of the alleged co-conspirators in a UK-based bomb plot involving a Canadian: "I have counted six Abduls, three Sheiks, an Adil, Atif and Asim, and three Alis, two of whom have it as a last name and the third as a first" (Blatchford 2008).

To some extent, media framings reflected the legal system's designation of particular acts as terroristic: the incidents most consistently labelled terrorism were the "Toronto 18" and Via Rail plots, which were charged as terrorism offences. Terrorism charges also produced an emphasis in coverage on the putative political, religious, or ideological motive for the attack, since proving such motive is a fundamental element of the legal process in terrorism cases. The significance of ideology in right-wing incidents, in contrast, was often discounted; Globe and Mail columnist Margaret Wente, for instance, 
described the misogynistic incel-inspired Toronto van rampage as a "random act of violence" lacking the "political, social and security implications" of a "terrorist attack" (Wente 2018; Kay 2018).

However, the identification of Muslims with terrorism exceeded formal legal designations. Abdulahi Hasan Sharif's non-fatal truck attack in Edmonton was labelled terrorism in media far more consistently (in 68\% of media items) than Alexandre Bissonnette's Quebec mosque shooting (in 13\%) (see Table 2)—although both were initially described as terrorism by political leaders, but neither were ultimately prosecuted under the terrorism provisions of the Criminal Code. The CBC described the Edmonton truck attack as "terrorism" even in apparent contravention of its own standards-branding it as a "terror attack" in headlines without quotation marks or attribution (for example: (CBC News 2017a, 2017b)), despite the fact that the broadcaster's guidelines state that journalists should "avoid labeling any specific bombing or assault as a terrorist act, unless the term is attributed [ ... ] [S]imply describe the act or individual, and let the viewer, the listener, the reader decide" (Swain 2017).

Right-wing and White supremacist violence was sometimes represented as excluded by definition from the domain of terrorism. For example, a Public Safety Canada study reported on in the National Post classified "violent extremist" and "supremacist" incidents (including the Moncton RCMP shooting) in a separate category from "terrorism" — even though "violent extremism" and "supremacism" ostensibly fit the Criminal Code definition of terrorism as violence committed for "political, religious, or ideological motive," for the purpose of intimidating the public or influencing governmental decisions or policy (Bell 2016). National Post editor and columnist Jonathan Kay pointed out that Justin Bourque's shooting alone had killed more people than "domestic terrorism" has in Canada since 9/11: an observation based on an unstated assumption that right-wing violence is not itself a type of terrorism (Kay 2014b; Simpson 2015). Reportage on the Moncton RCMP shooting trial described the murders as analogous to that of the Parliament Hill and Saint Jean-Sur-Richelieu attacks in their targeting of state actors- "all five men were targeted because of their uniforms" (Taber 2014)—but did not question the apparent inconsistency in the fact that the latter two were widely labelled "terrorism" while the former was not.

Articles about non-Muslim violence with "terrorism" in the headline were most often devoted to explaining why incidents like the Moncton RCMP shooting, the Halifax mall shooting plot, the Quebec mosque shooting, and the Toronto van attack did not qualify as "terrorism" (for example: (Kane 2015; CBC News 2017c; Carvin 2018; Rhodes 2015); an exception was (Roach 2018)). Academic and former national security analyst Stephanie Carvin argued in the Globe and Mail and on CBC that the incel-inspired Toronto van attack could not be considered terrorism, because the perpetrator Alek Minassian lacked any operational connection to an established terrorist group (Carvin 2018; CBC News 2018) - a criterion absent from the Criminal Code definition of "terrorism." Indeed, authorities asserted that Parliament Hill "lone wolf" attacker Michael Zehaf-Bibeau would have been tried for terrorism if he had survived, because even though he had acted alone he was apparently inspired by ISIS (CBC News 2015b).

Along similar lines, academic Michael Zekulin was quoted in a CBC article explaining that Moncton RCMP shooter Justin Bourque was not a terrorist (unlike Muslim perpetrators Michael Zehaf-Bibeau or Martin Couture-Rouleau), because his motivations for violence seemed to be more "personal" rather than oriented towards effecting "large-scale political change" (Gollom 2014)—even though Bourque admitted that he was attempting to spark an anti-government rebellion, and his own lawyer described him as "immersed" in "right-wing, gun-nut culture" (CBC News 2014a). The fact that Bourque had a Confederate flag, a symbol of White supremacist ideology, prominently displayed in his home received minimal attention: it was only referred to in two of the 372 articles pertaining to his case (Carlson and White 2014a; CBC News 2014b). A CBC photo album of images from evidence in the Bourque trial included one of the Confederate flag posted on his wall, but the caption underneath completely neglected to remark on the presence of the flag or explain its significance (CBC News 2014c). In contrast, the ISIS flag reportedly discovered in Edmonton rampager Abdulahi Sharif's car was regularly remarked upon as an indicator of his ideological motive (although 
Sharif was not ultimately charged with any terrorism offence) (for example: (Pruden et al. 2017b; Soupcoff 2017; CBC News 2017d)).

Even representations of right-wing and White supremacist violence as terroristic frequently served to ultimately entrench the framing of Muslim violence as the paradigmatic and most prevalent form of terrorism. For example, right-wing and racist violence were described as "non-classic" terrorism, "an unexpected face of extremism," and a less "significant" threat than Muslim violence (Leblanc 2017; Perreaux 2018; Perreaux and Freeze 2017) — even though right-wing and White-supremacist extremism has a much longer and bloodier history in Canada (Perry and Scrivens 2015). A more subtle representational structure with similar effect was the situation of instances of right-wing or White supremacist violence in a panoramic perspective featuring Muslim violence as predominant. For example, coverage of the Toronto incel van attack often listed numerous other examples of vehicular assaults around the world committed by individuals linked to Muslim organizations (for example: (Gee 2018; Clarke 2018; Pugliese 2018; Brewster 2018a))—while omitting to mention van attacks by White supremacists, like those at Charlottesville (US) or the Finsbury Park mosque (UK), and the fact that multiple states in the US have attempted to pass legislation inuring drivers who mow down anti-racism protestors from prosecution (Andone 2017). Globe and Mail columnist Doug Saunders included Justin Bourque in an analysis of "troubled young men" who have "turned to terror" —which also discussed Muslim assailants such as Michael Zehaf-Bibeau, Martin Couture-Rouleau, Michael Adebalajo (who killed British soldier Lee Rigby), and Fort Hood shooter Nidal Hasan, as well as other non-Muslims such as Norwegian anti-multiculturalism mass murderer Anders Breivik, Unabomber Theodore Kaczynski, and Oklahoma bomber Timothy McVeigh; and yet, all of the images accompanying the piece pertained to acts committed by Muslims, visually reinscribing the primacy of Muslim sources of "terror" (Saunders 2014).

\subsection{Identity Identified}

Non-White Muslim perpetrators were much more likely to be labelled by their religion, race, ethnicity, and citizenship status, in ways that connected them to groups represented as distinct from normative Canadian identity-while the racial and ethnic identities of White non-Muslim perpetrators were rarely mentioned (see Tables 2 and 3), preserving the invisibility and innocence of Whiteness. When coverage of Zehaf-Bibeau's Parliament Hill attack mentioned his ethno-racial identity, it primarily focused on his Libyan father, and not on his White Quebecois mother (for example: (Perreaux et al. 2014a, 2014b; Doolittle and White 2014)). Conversely, among non-Muslim perpetrators, media coverage most often identified the background of Lindsay Souvannarath, whose father is Southeast Asian, while ignoring the Whiteness of her co-conspirators Randall Shepherd and James Gamble (Bundale 2018; Hopper 2015).

Via Rail plotter Raed Jaser was described as a "dark-skinned man with a beard" (Perreaux et al. 2013), and several reports included commentary from neighbours on how he would exercise and share meals with men dressed in "traditional Muslim clothing"-insinuating that Muslim attire itself is a marker of suspicion (for example: (Bell et al. 2013; Brean and Humphreys 2013)). In several instances, a connection between "terrorism" and Muslims in general was asserted even more directly. The National Post's Lorne Gunter, for example, identified "the present state of Islamic culture" as the wellspring of global terrorism: a "metastasizing" "tumour" that "moderate Muslims themselves [must] excise" (Gunter 2006a). A Globe and Mail opinion piece on the "deadly contest under way between terrorists and their opponents in Western intelligence and security agencies" referred to Muslim communities as "communities that might harbour jihadists" (Wark 2006). Comparable characterizations of right-wing and White-supremacist extremists' communities of origin as collective "harbourers" of cancerous elements requiring eradication were absent.

For Muslim perpetrators, religious identity was regularly invoked as the presumed cause for violence; one CBC report on Parliament Hill shooter Michael Zehaf-Bibeau, for instance, noted that he was "a recent convert to Islam, which would be his motivation" (CBC News 2014e). Christian 
perpetrators, in contrast, were framed as engaging in violence in spite of their religious background. One of the Halifax mall plotters, Randall Shepherd, was described as a former attendant at Seventh Day Adventist church; "This is really shocking," one neighbour was quoted as commenting in the Globe and Mail, "The parents are good people. They attend church" (Tutton and Callanan 2015). Moncton shooter Justin Bourque's Christian background, when it was noted, was similarly represented as something that should have been a prophylactic against participation in violence, rather than a stimulant-even though a court-ordered psychiatric assessment of Bourque revealed that he grew up believing he was a "soldier of Christ" (MacKinnon 2014). In stark contradistinction to the fixation on Muslim identity as a motivator of bellicose "jihad," however, news reports on the Bourque case emphasised the incomprehensibility and tragedy of someone from a "good Catholic family" embarking on a path of mass violence. For example, the Globe and Mail cited neighbours of the Bourque family "express[ing] sadness at learning it was the son of 'good Catholic' parents who had sent Moncton into mourning" (Ha and Carlson 2014); "I think, because the family was such good Catholics, the mood will be sorry for them," commiserated one acquaintance quoted in another Globe story (Carlson and White 2014b; Montgomery 2014; CBC News 2014b).

Indeed, conversion from Christianity to Islam was presented as a risk factor for participation in violent extremist activity; a CSIS spokesperson quoted in the National Post, for instance, warned in a story about "homegrown terrorism" that "we have cases of white Anglo-Saxon male Protestants converting to the most radical Islam" (Bell 2006). National Post opinion columnist Barbara Kay argued that the parents of White men who convert to Islam and subsequently engage in "terrorism" deserve Canadians' sympathy, because they "brought [their children] up to consider hatred-based violence anything less than criminal and immoral" - unlike the parents of Muslim-born "terrorists," who "actually encourage and rejoice in their sons' homicidal martyrdom" (Kay 2014a).

Even reports of Muslim leaders and organizations condemning "terrorism" ultimately functioned to reinforce the assumption that Muslims are collectively implicated in terrorist violence unless proven otherwise, making such exercises of explicit dissociation necessary and intelligible (for example: (Globe and Mail Editorial Board 2013a; Freeze 2013; Woo 2014; Maki 2014; CBC News 2006, 2014d, 2014e; Desmarais 2017)). As Evelyn Alsultany points out, even ostensibly positive representations can serve to bolster problematically racialised systems of representation and control: "seemingly positive representations of Arabs and Muslims have helped to form a new kind of racism, one that projects antiracism and multiculturalism on the surface, but simultaneously produces the logics and affects necessary to legitimise racist policies and practices" (Alsultany 2012, p. 16). A CBC report on the role of the Muslim community in the pre-emptive thwarting of the Via Rail plot, for example, quoted an imam stating that he "welcomed" the presence of government agents in his mosque in order to foil terrorist plots (CBC News 2013a). The expectation that Muslim communities should disavow "terrorism," and accept collective securitization and surveillance as proof of patriotism, is underpinned by the projection of group Muslim responsibility for acts of violence committed by their nominal co-religionists: a burden not borne by the communities giving birth to right-wing or White supremacist perpetrators of violence, whose criminality is ascribed to individual delinquency rather than communal dysfunction.

\subsection{Pattern of Violence versus Isolated Incident}

Each individual act of Muslim violence routinely elicited invocations of a series of separate terror events connected by little except the religious identities of the perpetrators. For example, the Globe and Mail's "timeline of deadly attacks in Western nations since 2001" stitched together such disparate events as the train bombings in Madrid, Spain (2004), the attacks on the Underground in London, UK (2005), the army base shooting in Fort Hood, Texas (2009), a bombing in Stockholm, Sweden (2010), the Boston Marathon bombing (2013), the Parliament Hill and Saint Jean-Sur-Richelieu attacks (2014), and a hostage-taking in Sydney, Australia (2015), into a single chronology. Despite the fact that the timeline was framed generally as one of "deadly attacks in Western nations," the content was limited exclusively to incidents motivated by "violent jihadi extremism" — collapsed into a monolith, 
despite the diversity of actors, political motivations, and organizational affiliations encompassed by the category. Similarly "deadly attacks" from non-Muslim quarters, such as Anders Breivik's massacre of 77 people in Norway (2011), Justin Bourque's targeted shooting of RCMP officers in Moncton (2014), and Wade Michael Page's killing of six people at a Sikh gurdwara in Oak Creek, Wisconsin (2012), were neither included, nor made the subject of their own dedicated montage (The Globe and Mail 2015; similar compilations appeared in the National Post (Hensley 2015) and the CBC (CBC News 2013b)). In June 2017, the CBC hosted a "National Conversation" on "Terror," which was introduced with anchor Peter Mansbridge listing a series of "terrorism incidents" in various parts of the world, all committed by Muslims-“'London, Manchester, Paris, Kabul, Berlin, Ottawa, 9/11 [ ... ] we've all witnessed the horrific consequences"-but excluded the Quebec mosque shooting, which at the time that it occurred was the most fatal act of ideology-linked violence in Canada since 1989 (a fact that was almost never mentioned in coverage of the incident) (CBC News 2017e).

Incidents of violence by right-wing extremists and White supremacists were more likely to be represented as individual and isolated occurrences, purportedly notable for their rarity, singularity, and lack of coordination. Coverage of Alek Minassian's van attack in Toronto, for instance, only irregularly mentioned Elliot Rodger's 2014 misogynistic murder spree in Isla Vista, California, which killed six — even though Minassian explicitly referred to Rodger, and the "involuntarily celibate" ideology Rodger was associated with, as his inspiration. When a security analyst providing commentary on the CBC about the Finsbury Park mosque attack in London (UK) was asked by the anchor whether something similar could happen in Canada, he responded that it likely could not-apparently forgetting that a far more fatal attack on a mosque, Alexandre Bissonnette's mass shooting at the Islamic Cultural Centre of Quebec, had already occurred in Canada just five months earlier (CBC News 2017f). While each individual act of Muslim violence was interpolated as part of a larger canon of violence - enabled by the application of the unifying term "terrorism" to all such acts-instances of right-wing extremist and White supremacist violence were depicted as sporadic and unpredictable: "[a]ccording to CSIS, violence [by right-wing extremists] is usually infrequent, unplanned, and opportunistic, and is carried out by individuals rather than groups" (Bronskill 2018; Bell 2017).

When right-wing/White supremacist violence was situated as part of a broader pattern of violence, the pattern was frequently represented as highly localised rather than globalized, despite the fact that several right-wing and White supremacist groups in Canada are offshoots of European movements like PEGIDA and Soldiers of Odin. Coverage of the Quebec mosque shooting, for instance, noted other Islamophobic policy debates and incidents, particularly in the province of Quebec, as well as Donald Trump's "Muslim ban". However, it largely ignored the broader context of transnational Islamophobia characterised by assaults on mosques and Muslim community spaces across North America and Europe, and private and state-sponsored attacks on Muslims, including likely war crimes committed by Western governments and their allies in the "war on terror" (see, for example: (Bayrakli and Hafez 2018; Amnesty International 2014, 2018; Human Rights Watch 2014)).

Individual instances of Muslim "terrorism," in contrast, were depicted as the conjoined fruits of a unified "global jihadist movement" (for example: (Koring et al. 2006; Cheadle 2014; Martin 2013)). This framing replicates Canadian government policy documents conflating various violent incidents around the world as strands in a coherent tapestry of Muslim violence-so that even Canadian soldiers killed in Afghanistan have been counted as casualties of terrorism (Public Safety Canada 2013), despite the fact that most definitions specify that terrorism is violence wielded against civilians. In the universalizing perspective of post-9/11 counter-terrorism, "local skirmishes transcend their specific context and become battlefields for waging a global war on terror," as Gilles Kepel remarks (Kepel 2008, p. 182). Canada's "civilizational identity" (Arat-Koc 2005) as a member of "the West" is consolidated through participation in the transnational "war on (non-Western) terror"—-depicted as a Manichean "conflict between absolute evil and civilization," in the words of National Post contributor Conrad Black (Black 2014)—while the racial underpinnings connecting military violence against Muslims abroad, with governmental and private violence against Muslims and other racialised communities at home, remain obscured. 


\subsection{Motivations for Violence}

The disproportionate fixation on Muslim violence fosters an impression that racist attacks against Muslims are an unfortunate but predictable response to Muslim "terrorism" (Ahmad 2004)—even though studies suggest that rates of Islamophobia are more closely correlated to levels of Islamophobia in domestic political discourse than acts of Muslim violence (Hussain and Saleh 2018). One particularly striking example was the CBC's analysis the evening of the Finsbury Park mosque attack in London, UK, which focused on the mosque's supposed history of extremism from over a decade ago, and emphasised the risk of ISIS using the attack to bolster its anti-Western narrative in the future (CBC News 2017f), while ignoring the recent spate of Islamophobic hate incidents in the area and the murder of a Muslim teenaged girl in the US the day before (Ganesh 2017): so that even while the incident being discussed was an episode of hatred against Muslims, the entire frame surrounding the discussion figured Muslims as the perpetrators of violence rather than victims (Noor Cultural Centre 2017).

In contrast, the recognition that Muslim perpetrators of violence frequently cited Canada's involvement in the US-led military ventures in Afghanistan and Iraq as their motivation was unaccompanied by any acknowledgement of - and in some cases an overt refusal to acknowledge (for example: (Mack 2013; Brown 2014; Bell 2014a)) — the abuses and violence endemic in these ventures, which have included the alleged indiscriminate killing of civilians, widespread destruction of homes, hospitals, and other necessities for civilian life, and complicity in torture (for example: (Amnesty International 2014; Gall 2010; Sabry 2015)). Instead, opposition to Canadian forces' participation in the "war on terror" was depicted as symptomatic of an idiopathic hated of "the West," arising from a rabid "Islamic extremism" rather than any rational political grievance (Abrahamian 2003; Poole 2011). Indeed, the Globe and Mail editorial board dismissed as "foolish" Liberal Party leader Justin Trudeau's suggestion that the "root causes" of terrorism needed to be understood (Globe and Mail Editorial Board 2013b). As Lorne Gunter smugly opined in the National Post, "Islamists hate Western ideals [like tolerance] [ ... ] We could let Muslims practice sharia law within their own community and guarantee Muslim students and employees set-aside space at schools and work for their five-times-daily prayers, and still the jihadists among us would conspire to buy explosives and plot to blow up Canadian targets until we all agreed to live under sharia law and worship Allah at dawn, mid-morning, noon, mid-afternoon and dusk" (Gunter 2006b). While a video recorded by Parliament Hill attacker Michael Zehaf-Bibeau before his assault condemned Canada's foreign policy, it was the fact that he had also "praised Allah" that was often seized upon as the most salient, sensational, and sinister detail in demonstrating the terroristic nature of his motive. The Globe and Mail headline on its story about the release of the video announced that the "Ottawa shooter referred to Allah in video" (Wingrove 2014a), while the CBC's subheadline informed readers that "Unreleased portion [of the video] includes two prayers to Allah, both of which are spoken in Arabic" (Watters 2015).

\subsection{Significance of Mental Health}

Coverage of violence by Muslim perpetrators was more likely to mention issues of mental health (see Table 3). This was particularly the case when analysis of the mental health of the accused was an important part of the court process - as in the Via Rail trial (see Table 2), in the course of which one of the perpetrators, Chiheb Esseghaier, was diagnosed as being "actively psychotic" and suffering from untreated schizophrenia (for example: (Mehta 2015; Brean 2015; Warnica 2015; Warnica 2017)). Significantly, however, media coverage was still far more concerned with Esseghaier's putative "Islamic extremist" ideology than the schizophrenia diagnosis-more than four times as many articles on the case mentioned the plotters' ideology as mentioned mental health—so that even signs of Esseghaier's dysfunction, such as the fact that he was effectively homeless and sleeping in a train station, were construed by some commentators as portents of threat rather than indicators of mental illness and hardship. For instance, the National Post likened Esseghaier to a gangster character in the French film Subway, who "evades police by taking refuge in the murky depths of the Paris Metro" (National Post 2013). 
While mental health was sometimes invoked to dispute the characterization of an incident of Muslim violence as "terrorism," other commentators emphasised that the two were not mutually exclusive (for example: (Wente 2014; Picard 2014)), or argued that "Islamic extremism" itself constituted a form of psychopathy. For example, Terry Glavin asserted in the National Post that it is "not just possible to be insane and a jihadi terrorist at the same time-it's more or less mandatory" (Glavin 2016).

\subsection{State Response}

Media discussions of Muslim violence involved extensive debates about legal and policy changes to increase the efficacy of counter-terrorism, including through increasingly pre-emptive measures with troubling implications for fundamental rights and civil liberties (Payton 2015; United Nations 2016): legislation dramatically expanding the powers of security agencies to conduct surveillance and engage in preventive detention, such as Bills C-44 and C-51; and counter-radicalization programs targeting exercises of free expression deemed precursors to "violent extremism" by the state, frequently on spurious grounds (for example: (Chase 2013a, 2013b; Silcoff 2014; Wingrove 2014b; Wingrove and Taber 2014; Pruden et al. 2017a; Bell 2009, 2014b; Bell and Carlson 2011; Elliott 2014; Carter 2014) for critiques of the formulation of counter-radicalization programs see (Kundnani 2014; Patel 2011)). When Muslim perpetrators of violence have also been refugees or asylum seekers-like Via Rail plotter Raed Jaser, whose background as a Palestinian asylum seeker was regularly highlighted in media reports, or Abdulahi Hasan Sharif, whose status as a Somali refugee was similarly emphasized (see Table 2) - the question of how Canada's refugee and immigration system might be amended to bar the gates more strongly against future would-be "terrorists" has been an additional subject of concern (for example: (Friesen 2017; Morrow 2017; Canadian Press 2013; Bell 2013a, 2013b)). These emphases in media discourse largely reflected the content of official political debates in the wake of Muslims incidents of violence; however, journalists also independently raised concerns about the adequacy of existing pre-emptive counter-terrorism measures following the Parliament Hill and Saint Jean-Sur-Richelieu attacks by Muslim perpetrators (for example: (Mayer 2014; Hall 2014; Peritz 2014; Postmedia News 2014)).

Media coverage of far more fatal incidents of violence by non-Muslim perpetrators driven by right-wing and White supremacist ideologies, in contrast, was largely divorced from consideration of systemic changes to laws, policies, and surveillance practices (Clark 2017). After the incel-inspired Toronto van attack - which overtook the Quebec mosque shooting as the most deadly act of public violence in Canada in the last two decades-National Security Minister Ralph Goodale admitted that he was largely unfamiliar with "involuntarily celibate" ideology, and that security agencies were unlikely to intensively monitor the incel community in the future (Hayes and Gray 2018). The CBC quoted former CSIS analyst Phil Gurski maintaining that "from a CSIS perspective, it [incel] would not fit the mandate as a threat to Canada using violence from an ideological perspective" - despite the fact that incel has been classified as a form of hateful "male supremacist" ideology by the Southern Poverty Law Center (Hayes and Gray 2018; Brewster 2018b; Southern Poverty Law Center 2017).

The focus of concern in the aftermath of right-wing attacks has been primarily on proposing measures to mitigate the destructive potential of future such events-by arming the RCMP more heavily in the wake of Justin Bourque's rampage (for example: (Bissett 2016; Thomson 2017; Carlson 2014; Vanta 2015; Gurney 2015)), or by erecting bollards and implementing other technical road-safety measures in cities to reduce the damage of van attacks like Alek Minassian's (for example: (Matteis and Davis 2018; Bozikovic 2018; Moore 2018; Hamilton 2018))—with rarely any suggestion that the fellow adherents of their ideologies, or members of their religious and ethnic communities, should be subjected to the type of pre-emptive surveillance and communal securitization imposed on Muslim communities in the name of preventing "terrorism." 


\section{Conclusions}

Media is a powerful shaper of public perceptions regarding the threat of political and ideological violence. The patterns of representation analyzed above coalesce to frame Muslim violence as an exceptional problem ("terrorism") requiring exceptional solutions. A 2018 survey by the Angus Reid Institute and Canadian Race Relations Foundation found that Canadians are significantly more concerned about the threat posed by "homegrown radical Islamic terrorism" than by White supremacists/nationalists (Angus Reid Institute and Canadian Race Relations Foundation 2018)—despite the fact that White supremacist and extreme right-wing violence has been far more frequent and fatal in Canada (Perry and Scrivens 2015; Monaghan and Molnar 2016). In the Environics Institute's 2016 survey of Muslims in Canada, a majority (52\%) reported being worried about violent extremism among Muslim Canadians, even though only a very small percentage (3\%) had actually seen or heard extremism being promoted in community spaces (Environics Institute 2016)—suggesting that the "double consciousness" (DuBois 1903) instilled by pervasive public representations of the threat of Muslim violence is powerful enough to override Muslims' direct experiences of their own communities. Media representations not only skew perceptions regarding the incidence and etiology of ideological violence, but also tilt the terrain of public debate on appropriate measures to adopt in response: research indicates that people are more likely to endorse the erosion of civil liberties for the purpose of countering terrorism after exposure to discourse painting Muslim terrorism as a threat (Brinson and Stohl 2012; Woods 2011).

However, as Judith Butler reminds us, frames are not immutable; the fact that frames depend on constant reiteration in order to install themselves as reality means that they are vulnerable to being reconfigured and repurposed for critical ends. "What happens when a frame breaks with itself is that a taken-for-granted reality is called into question, exposing the orchestrating designs of the authority who sought to control the frame [ ... ] As frames break from themselves in order to install themselves, other possibilities for apprehension emerge," rendering hegemonic renditions of reality susceptible "to reversal, to subversion, even to critical instrumentalization" (Butler 2009, pp. 10, 12). Exposure of the "orchestrating designs" behind the framing of the Muslim threat in the "war on terror" enables the emergence of different frames, ones that subvert rather than perpetuate the racial formations sustaining policies of collective criminalization and endless war.

Funding: This research received no external funding.

Acknowledgments: I would like to thank the editor of this special volume, Idrisa Pandit, and the two anonymous reviewers who provided helpful remarks on an earlier draft of this paper.

Conflicts of Interest: The author declares no conflict of interest.

\section{References}

Abrahamian, Ervand. 2003. The US Media, Huntington and September 11. Third World Quarterly 24: 529. [CrossRef]

Ahmad, Muneer I. 2004. A Rage Shared by law: Post-September 11 Racial Violence as Crimes of Passion. California Law Review 92: 1259. [CrossRef]

Ahmed, Saifuddin, and Jorg Matthes. 2016. Media Representation of Muslims and Islam from 2000 to 2015 : A Meta-Analysis. International Communication Gazette 79: 219. [CrossRef]

Alsultany, Evelyn. 2012. Arabs and Muslims in the Media: Race and Representation after 9/11. New York: New York University Press.

Amnesty International. 2014. Left in the Dark: Failures of Accountability for Civilian Casualties Caused by International Military Operations in Afghanistan. Available online: https:/ /www.amnesty.org/en/ documents / ASA11/006/2014/en/ (accessed on 15 July 2018).

Amnesty International. 2018. War of Annihilation: Devastating Toll on Civilians, Raqqa-Syria. Available online: https:/ / www.amnesty.org/en/documents/mde24/8367/2018/en/ (accessed on 15 July 2018). 
Andone, Dakin. 2017. These States Have Introduced Bills to Protect Drivers Who Run over Protesters. CNN, August 19. Available online: https://www.cnn.com/2017/08/18/us/legislation-protects-drivers-injureprotesters/index.html (accessed on 15 July 2018).

Angus Reid Institute and Canadian Race Relations Foundation. 2018. Radicalization and Homegrown Terrorism: Four-in-Ten Say Radicalized Individuals Live in their Communities. Available online: http:/ /angusreid.org/ radicalization-homegrown-terrorism/ (accessed on 15 July 2018).

Arat-Koc, Sedef. 2005. The Disciplinary Boundaries of Canadian Identity after September 11: Civilizational Identity, Multiculturalism, and the Challenge of Anti-Imperialist Feminism. Social Justice 32: 32-49.

Bayrakli, Enes, and Farid Hafez. 2018. European Islamophobia Report 2017. Available online: https:/ /www. islamophobiaeurope.com/wp-content/uploads/2018/04/EIR_2017.pdf (accessed on 15 July 2018).

Belkhodja, Chedly, and Chantal Richard. 2006. The Events of September 11 in the French-Canadian Press. Canadian Ethnic Studies 38: 119.

Bell, Stewart. 2006. Arrests in Terror Raid: At Least Nine Nabbed, One Suspect Sought. National Post, June 3.

Bell, Stewart. 2009. Ottawa Using Intervention to Extinguish Extremism; Muslim Outreach. National Post, January 31. Bell, Stewart. 2013a. Terror Suspect could not Be Deported; Jaser a Stateless Palestinian. National Post, April 26.

Bell, Stewart. 2013b. Kenney Wants Answers over via Rail Suspects; 'Why Should Pardon Override Criminal Inadmissability?'. National Post, April 27.

Bell, Stewart. 2014a. Terror Suspect Rails at Canada; Chiheb Esseghaier Decries Mission to Afghanistan in Interview. National Post, February 5.

Bell, Stewart. 2014b. RCMP Tacking Extremism at Home; Tools for Police; Program to Fight Radicalization of Canadian Youth. National Post, March 5.

Bell, Stewart. 2016. Religion New No. 1 Terror Motive; Has Overtaken Environment, Study Finds. National Post, October 31.

Bell, Stewart. 2017. Far Right not thought Violent, Ex-Spy Chief Says. National Post, February 1.

Bell, Stewart, and Kathryn Blaze Carlson. 2011. Tories Aim to Fill Terrorism Law Gaps; Two New Measures. National Post, November 16.

Bell, Stewart, Joe O'Connor, Adrian Humphreys, and Sarah Boesveld. 2013. Police Thwart Plot to Derail Train; Suspects Had 'Capacity and Intent,' Police Say. National Post, April 23.

Bissett, Kevin. 2016. Thousands of RCMP Given Long-Gun Training in Wake of Moncton Shootings. The Globe and Mail, February 9. Available online: https://www.theglobeandmail.com/news/national/thousands-ofmounties-given-long-gun-training-in-wake-of-moncton-shootings/article28677597/ (accessed on 5 July 2018).

Black, Conrad. 2014. Conflict Between Evil, Civilization; Incidents Show Canada is Right to Be Aligned against Agents of Terror and their Sponsors. National Post, October 23.

Blatchford, Christie. 2008. The Naming of Names and Knowing Thy Enemy. The Globe and Mail, June 25. Available online: https://www.theglobeandmail.com/news/national/the-naming-of-names-and-knowingthy-enemy/article720505/ (accessed on 3 July 2018).

Bourrie, Mark. 2016. Deprogramming the Jihadi: A New Book Explores How Canadian Police Are Waging a Slow War on the Enemy within. National Post, August 26.

Bozikovic, Alex. 2018. We can't Stop Every Attacker-But with Better Roads, We can Save Lives. The Globe and Mail, May 1. Available online: https:/ / www.theglobeandmail.com/canada/toronto/article-we-cant-stopevery-attacker-but-with-better-roads-we-can-save/ (accessed on 5 July 2018).

Brean, Joseph. 2015. 'Psychotic' Diagnosis in Via Rail Plot Trial. National Post, July 15.

Brean, Joseph, and Adrian Humphreys. 2013. Suspect's Religious Views 'Frustrated' Colleagues. National Post, April 23.

Brewster, Murray. 2018a. Trudeau, Goodale Try to Reassure Canadians and the World in the Wake of Deadly Van Attack. CBC News, April 23. Available online: https:/ / www.cbc.ca/news/politics/g7-toronto-van-attack-1. 4632443 (accessed on 11 July 2018).

Brewster, Murray. 2018b. Terror without Ideology: Can Authorities Track the Violent Subculture Linked to Monday's Van Attack? CBC News, April 25. Available online: http://www.cbc.ca/news/politics/specialforces-van-attack-1.4635704 (accessed on 11 July 2018).

Brinson, Mary E, and Michael Stohl. 2012. Media Framing of Terrorism: Implications for Public Opinion, Civil Liberties, and Counterterrorism Policies. Journal of International and Intercultural Communication 5: 270. [CrossRef] 
Bronskill, Jim. 2018. CSIS Ended Investigation of Right-Wing Extremism 10 Months Before Quebec City Mosque Shooting: Report. The Globe and Mail, June 20. Available online: https:/ / www.theglobeandmail.com/canada/ article-csis-ended-investigation-of-right-wing-extremism-10-months-before/ (accessed on 4 July 2018).

Brown, Ian. 2014. In the Wake of Shooting, Ottawans Talk Politics: Things Will Change on the Hill. The Globe and Mail, October 23. Available online: https:/ / www.theglobeandmail.com/news/national/in-wake-of-ottawashooting-theories-abound-things-will-change-on-the-hill/article21256594/ (accessed on 3 July 2018).

Bullock, Katherine H., and Gul Joya Jafri. 2000. Media (Mis)Representations: Muslim Women in the Canadian Nation. Canadian Women Studies 20: 35.

Bundale, Brett. 2018. Parents of Woman Convicted in Halifax Mall Shooting Plot Say She's not Capable of Violence. The Globe and Mail, April 23. Available online: https:/ / www.theglobeandmail.com/canada/article-parentsof-woman-convicted-in-halifax-mall-shooting-plot-say-shes-not/ (accessed on 5 July 2018).

Butler, Judith. 2009. Frames of War: When Is Life Grievable? New York: Verso.

Canadian Network for Research on Terrorism, Security and Society. n.d. Canadian Incident Databased. Available online: http:/ / extremism.ca/ (accessed on 2 July 2018).

Canadian Press. 2013. Immigration Minister Jason Kenney to Look at Deportations in Wake of Via Rail Plot. The Globe and Mail, April 26. Available online: https:/ / www.theglobeandmail.com/news / politics / immigration-minister-jason-kenney-to-look-at-deportations-in-wake-of-via-rail-plot/article11574641/ (accessed on 3 July 2018).

Carlson, Kathryn Blaze. 2014. RCMP Officers' Deaths Prompt Safety Probes. The Globe and Mail, June 18. Available online: https:/ / www.theglobeandmail.com/news/national/rcmp-officers-deaths-prompt-safety-probes / article19233702/ (accessed on 4 July 2018).

Carlson, Kathryn Blaze, and Patrick White. 2014a. Moncton Shooting Suspect's Friend Charged with Uttering Death Threats. The Globe and Mail, June 9. Available online: https://www.theglobeandmail.com/ news/national/moncton-suspects-home-military-toys-heavy-metal-posters-and-a-confederate-flag/ article19074823/ (accessed on 4 July 2018).

Carlson, Kathryn Blaze, and Patrick White. 2014b. Noise of Gunfire Still Echoes for Malihot Avenue Residents in Moncton. The Globe and Mail, June 6. Available online: https://www.theglobeandmail.com/news/national/ noise-of-gunfire-still-echoes-for-mailhot-avenue-residents-in-moncton/article19061408/ (accessed on 4 July 2018).

Carter, Adam. 2014. Hamilton Lawyer Saved 10 Young People from Terror Extremism. CBC News, November 6. Available online: http:/ / www.cbc.ca/news/canada/hamilton/news/hamilton-lawyer-saved-10-youngpeople-from-terror-extremism-1.2825965 (accessed on 9 July 2018).

Carvin, Stephanie. 2018. It Invoked Terror-But We Can't Call the Toronto Van Attack Terrorism. The Globe and Mail, April 24. Available online: https:/ /www.theglobeandmail.com/opinion/article-it-invoked-terror-butwe-cant-call-the-toronto-van-attack-terrorism/ (accessed on 5 July 2018).

CBC News. 2006. Islam Not Violent, Toronto Muslims Say. CBC News, June 4. Available online: https:/ /www.cbc. $\mathrm{ca} /$ news / canada/islam-not-violent-toronto-muslims-say-1.584450 (accessed on 9 July 2018).

CBC News. 2013a. What the Analysts Are Saying about Alleged Train Plot. CBC News, April 23. Available online: http:/ / www.cbc.ca/news/canada/what-the-analysts-are-saying-about-alleged-train-plot-1.1312247 (accessed on 9 July 2018).

CBC News. 2013b. Canadians Who Have 'Fallen Prey' to Islamic Extremism. CBC News, April 2. Available online: http:/ / www.cbc.ca/news/canada/canadians-who-have-fallen-prey-to-islamic-extremism-1.1314368 (accessed on 9 July 2018).

CBC News. 2014a. Justin Bourque's Lawyer Slams Gun Laws. CBC News, October 31. Available online: https:/ / www.cbc.ca/news/canada/new-brunswick/justin-bourque-s-lawyer-slams-gun-laws-1.2820233 (accessed on 10 July 2018).

CBC News. 2014b. Justin Bourque: Latest Revelations about Man Charged in Moncton Shooting. CBC News, June 5. Available online: http://www.cbc.ca/news/canada/new-brunswick/justin-bourque-latest-revelationsabout-man-charged-in-moncton-shooting-1.2665900 (accessed on 10 July 2018).

CBC News. 2014c. Justin Bourque Trial Evidence. CBC News, December 5. Available online: http:/ /www.cbc.ca/ news/canada/new-brunswick/justin-bourque-trial-evidence-1.2862805 (accessed on 10 July 2018).

CBC News. 2014d. RCMP Foster Muslim Ties to Thwart Attacks. CBC News, March 31. Available online: http: / / www.cbc.ca/news/canada/rcmp-foster-muslim-ties-to-thwart-attacks-1.2501160 (accessed on 9 July 2018). 
CBC News. 2014e. Ottawa Shooter's Vancouver Connection. CBC News, October 22. Available online: http:// www.cbc.ca/news/canada/british-columbia/ottawa-shooter-s-vancouver-connection-1.2809849 (accessed on 9 July 2018).

CBC News. 2015a. Alleged Halifax Shooting Plotters 'Were Prepared to Wreak Havoc and Mayhem. CBC News, February 14. Available online: http:/ / www.cbc.ca/news/canada/nova-scotia/alleged-halifax-shootingplotters-were-prepared-to-wreak-havoc-and-mayhem-1.2957767 (accessed on 10 July 2018).

CBC News. 2015b. 6 Things We Learned about Michael Zehaf-Bibeau and Parliament Hill Shooting. CBC News, March 6. Available online: http:/ / www.cbc.ca/news/politics/6-things-we-learned-about-michael-zehafbibeau-and-parliament-hill-shooting-1.2984759 (accessed on 9 July 2018).

CBC News. 2017a. The Latest on the Terror Attack in Edmonton. Available online: http:/ /www.cbc.ca/news/ canada/edmonton/programs/edmontonam/the-latest-on-the-terror-attack-in-edmonton-1.4316742 (accessed on 9 July 2018).

CBC News. 2017b. Mayor Don Iveson Reflects on the Terror Attacks over the Weekend in Edmonton. Available online: http:/ / www.cbc.ca/listen/shows/edmonton-am/episode/14236966 (accessed on 9 July 2018).

CBC News. 2017c. Why the Accused in Quebec City Mosque Shooting Isn't Likely to Face Terrorism Charges. CBC News, February 1. Available online: http://www.cbc.ca/news/canada/montreal/why-accused-inquebec-city-mosque-shooting-isn-t-likely-to-face-terrorism-charges-1.3961837 (accessed on 11 July 2018).

CBC News. 2017d. 'Was He Under Surveillance?': Questions Surround Edmonton 'Acts of Terrorism,' Security Expert Says. CBC News, October 1. Available online: http://www.cbc.ca/news/canada/edmonton/ edmonton-terrorism-jasper-avenue-security-police-1.4315618 (accessed on 9 July 2018).

CBC News. 2017e. The National. CBC News, June 5.

CBC News. 2017f. The National. CBC News, June 19.

CBC News. 2018. Should Online Misogyny Be Considered Terrorism? Available online: http://www.cbc.ca/ player/play/1221940803672 (accessed on 11 July 2018).

Chase, Steven. 2013a. Parliament Debates Giving Police More Power to Detain Terror Suspects. The Globe and Mail, April 23. Available online: https:/ / www.theglobeandmail.com/news/politics/tories-to-table-expandedsecurity-bill/article21311502/ (accessed on 3 July 2018).

Chase, Steven. 2013b. Via Rail Train Plot Brings Counterterrorism, Civil Liberties to Top of House's Agenda. The Globe and Mail, April 22. Available online: https:/ /www.theglobeandmail.com/news/politics/via-railtrain-plot-brings-counterterrorism-civil-liberties-to-top-of-houses-agenda/article11464897/ (accessed on 3 July 2018).

Cheadle, Bruce. 2014. Ottawa Terror Attack Named Canadian Press News Story of 2014. Toronto: Canadian Press.

Clark, Campbell. 2017. Trudeau's Homily about the Quebec City Mosque Attack Demands a Call for Healing. The Globe and Mail, January 30. Available online: https: / www.theglobeandmail.com/news / politics/quebeccity-mosque-shooting-trudeau-response/article33844900/ (accessed on 5 July 2018).

Clarke, Colin P. 2018. The Continuing Plague of Vehicle Attacks: What Can Be Done? The Globe and Mail, April 25. Available online: https:/ / www.theglobeandmail.com/opinion/article-the-continuing-plague-of-vehicleattacks-what-can-be-done/ (accessed on 5 July 2018).

CSIS. 2017. Public Report 2014-2016. Available online: https:/ / www.canada.ca/en/security-intelligence-service/ corporate/publications/public-report-2014-2016.html (accessed on 16 July 2018).

Desmarais, Anna. 2017. Muslim Community Denounces Edmonton Attacks in Special Sermon. CBC News, October 7. Available online: http:/ / www.cbc.ca/news/canada/edmonton/edmonton-muslim-communitydenounce-attacks-1.4345210 (accessed on 9 July 2018).

Doolittle, Robyn, and Patrick White. 2014. Ottawa Gunman Sought Libyan Passport Three Weeks before Attack. The Globe and Mail, October 24. Available online: https:/ /www.theglobeandmail.com/news/national/ottawagunman-sought-libyan-passport-three-weeks-before-attack/article21287097/ (accessed on 3 July 2018).

DuBois, W. E. B. 1903. The Souls of Black Folk. New York: Penguin Random House.

Elliott, Louise. 2014. Ottawa Shooting: Harper Government Wants to Make Terror Arrests Easier. CBC News, October 24. Available online: http://www.cbc.ca/news/politics/ottawa-shooting-harper-governmentwants-to-make-terror-arrests-easier-1.2811571 (accessed on 9 July 2018).

Entman, Robert M. 1993. Framing: Toward Clarification of a Fractured Paradigm. Journal of Communication 43: 51-68. [CrossRef] 
Environics Institute. 2016. Survey of Muslims in Canada 2016. Available online: https:/ /www.environicsinstitute. org/docs / default-source/ project-documents / survey-of-muslims-in-canada-2016/ final-report.pdf? sfvrsn=fbb85533_2 (accessed on 15 July 2018).

Fisk, Robert. 2006. How Racism Has Invaded Canada. The Independent, June 10. Available online: https:/ / www. independent.co.uk/voices/commentators/fisk/robert-fisk-how-racism-has-invaded-canada-8696865.html (accessed on 13 July 2018).

Forcese, Craig. 2016. Completed Terrorism Prosecutions in Canada: Updated Table. Available online: http:/ / craigforcese.squarespace.com/national-security-law-blog/2016/9/14/completed-terrorismprosecutions-in-canada-updated-table.html (accessed on 2 July 2018).

Forcese, Craig, and Kent Roach. 2015. False Security: The Radicalization of Canadian Anti-Terrorism. Toronto: Irwin Law.

Freeze, Colin. 2009. Crown to Appeal Sentence for Toronto 18 Member. The Globe and Mail, October 1. Available online: https:/ / www.theglobeandmail.com/news/national/crown-to-appeal-sentence-for-toronto-18member/article1203029 / (accessed on 3 July 2018).

Freeze, Colin. 2013. How Faith Built a Fragile Trust Between Police, Muslim Community. The Globe and Mail, April 25. Available online: https://www.theglobeandmail.com/news/national/how-faith-built-a-fragiletrust-between-police-muslim-community/article11540816/ (accessed on 3 July 2018).

Friesen, Joe. 2017. Ottawa to Examine Possible Changes to Asylum System after Edmonton Attack. The Globe and Mail, October 4. Available online: https:/ / www.theglobeandmail.com/news/national/ottawa-to-examinepossible-changes-to-asylum-system-after-edmonton-attack/article36497543/ (accessed on 3 July 2018).

Gall, Carlotta. 2010. In Afghan South, US Faces Frustrated Residents. New York Times, October 16. Available online: https:/ / www.nytimes.com/2010/10/17/world/asia/17afghan.html?pagewanted=2\&_r=1\&sq= afghanistan\%20canadian\&st=cse\&scp=6 (accessed on 15 July 2018).

Ganesh, Bharath. 2017. Finsbury Park Attack Shows the Harm Islamophobia Continues to Inflict on Muslim Communities. The Conversation, June 19. Available online: https://theconversation.com/finsbury-parkattack-shows-the-harm-islamophobia-continues-to-inflict-on-muslim-communities-79682 (accessed on 15 July 2018).

Gee, Marcus. 2018. The Lesson from the Van Attack: Toronto is Strong Enough to Heal. The Globe and Mail, April 23. Available online: https://www.theglobeandmail.com/canada/toronto/article-van-attack-was-aprofound-shock-to-toronto/ (accessed on 5 July 2018).

Glavin, Terry. 2016. Choose Your Own Narrative: Everyone Seems to have a Theory about What Inspired Omar Mateen. The Truth May Be Far More Complex. National Post, June 16.

Globe and Mail Editorial Board. 2009. Far, Far From Harmless. The Globe and Mail, October 10. Available online: https:/ / www.theglobeandmail.com/opinion/editorials/far-far-from-harmless/article4290591/ (accessed on 3 July 2018).

Globe and Mail Editorial Board. 2013a. Imam Who Reported Terror Suspects to Authorities Was Doing His Duty. The Globe and Mail, April 23. Available online: https:/ /www.theglobeandmail.com/opinion/editorials / imam-who-reported-terror-suspect-to-authorities-was-doing-his-duty/article11494309/ (accessed on 3 July 2018).

Globe and Mail Editorial Board. 2013b. Why Canada Needs to Remain Vigilant on Terrorism. The Globe and Mail, April 22. Available online: https://www.theglobeandmail.com/opinion/editorials/why-canada-needs-toremain-vigilant-on-terrorism/article11477089/ (accessed on 3 July 2018).

Gollom, Mark. 2014. Ottawa Attack: Was Michael Zehaf-Bibeau's Attack a Terrorist Act. CBC Nezws, October 30. Available online: http: / www.cbc.ca/news/canada / ottawa-attack-was-michael-zehaf-bibeau-s-attack-aterrorist-act-1.2818329 (accessed on 9 July 2018).

Gunter, Lorne. 2006a. Wilfully Blind to Terror's Source. National Post, August 14.

Gunter, Lorne. 2006b. It Was Only a Matter of Time. National Post, June 5.

Gurney, Matt. 2015. Cops with Carbines. National Pot, May 19.

Ha, Tu Thanh, and Kathryn Blaze Carlson. 2014. Shocked Residents Describe Moncton Suspect's 'Cold Glare,' Bizarre Behaviour. The Globe and Mail, June 6. Available online: https:/ /www.theglobeandmail.com/news/ national/shocked-residents-describe-moncton-suspects-cold-glare-bizarre-behaviour/article19040909/ (accessed on 5 July 2018). 
Hall, Chris. 2014. Has Ottawa Been Too Slow to Take on Radicalized Canadians? CBC News, October 9. Available online: https: / / www.cbc.ca/news / politics/has-ottawa-been-too-slow-to-take-on-radicalized-canadians1.2793124 (accessed on 9 July 2018).

Hamilton, Graeme. 2018. Rethinking Streetscapes after Yonge St. National Post, April 28.

Hayes, Molly, and Jeff Gray. 2018. Investigators Turn Attention to Motive as Toronto Van Attack Suspect Charged with 10 Counts of Murder. The Globe and Mail, April 24. Available online: https:/ / www.theglobeandmail. $\mathrm{com} /$ canada/article-alek-minassian-faces-multiple-counts-of-first-degree-attempted-murder/ (accessed on 5 July 2018).

Hensley, Laura. 2015. The Influence of ISIS. National Post, June 27.

Hopper, Tristin. 2015. Odd Fixation on Nazi Symbols. National Post, February 18.

Huff, Connor, and Joshua D. Kertzer. 2018. How the Public Defines Terrorism. American Journal of Political Science 62: 55. [CrossRef]

Human Rights Watch. 2014. A Wedding that Became a Funeral: US Drone Attack on Marriage Procession in Yemen. Available online: https://www.hrw.org/report/2014/02/19/wedding-became-funeral/us-droneattack-marriage-procession-yemen (accessed on 15 July 2018).

Hussain, Murtaza, and Maryam Saleh. 2018. Bigoted Election Campaigns, Not Terror Attacks, Drive Anti-Muslim Activity. The Intercept, March 11. Available online: https://theintercept.com/2018/03/11/anti-muslimactivities-politics-terrorism-islamophobia / (accessed on 15 July 2018).

Institute for Social Policy and Understanding. 2018. Equal Treatment? Measuring the Legal and Media Responses to Ideologically Motivated Violence in the United States. Available online: https:/ /www.imv-report.org/ (accessed on 1 July 2018).

Ismael, Tareq Y., and John Measor. 2003. Racism and the North American Media Following 11 September: The Canadian Setting. Arab Studies Quarterly 25: 101.

Ivison, John. 2014. Canada Will Take Needed Steps: Harper; Prime Minister Condemns 'Brutal' Attack. National Post, October 23.

Jiwani, Yasmin. 2004. Gendering Terror: Representations of the Orientalized Body in Quebec's Post-September 11 English-Language Press. Critique: Critical Middle Eastern Studies 13: 265. [CrossRef]

Jiwani, Yasmin. 2005a. The Great White North Encounters September 11: Race, Gender, and Nation in Canada's National Daily, The Globe and Mail. Social Justice 32: 50.

Jiwani, Yasmin. 2005b. 'War Talk' Engendering Terror: Race, Gender and Representation in Canadian Print Media. International Journal of Media and Cultural Politics 1: 15. [CrossRef]

Jiwani, Yasmin. 2014. A Clash of Discourses: Femicides or Honour Killings? In Re-Imagining the Other: Culture, Media, and Wester-Muslim Intersections. Edited by Mahmoud Eid and Karim Karim. Berlin: Springer, p. 122.

Jiwani, Yasmin, and Matthew Dessner. 2016. Barbarians in/of the Land: Representations of Muslim Youth in the Canadian Press. Journal for Contemporary Issues in Education 11: 36. [CrossRef]

Kane, Laura. 2015. Legal Distinction between Terrorists and Criminals is 'Hazy,' Experts Say. The Globe and Mail, February 15. Available online: https:/ / www.theglobeandmail.com/news/national/legal-distinctionbetween-terrorists-and-criminals-is-hazy-experts-say/article23010078/ (accessed on 5 July 2018).

Kanji, Azeezah. 2018. The Persistent Gaslighting of Muslims about Islamophobia. Toronto Star, February 8. Available online: https:/ /www.thestar.com/opinion/contributors/2018/02/08/the-persistent-gaslightingof-muslims-about-islamophobia.html (accessed on 15 July 2018).

Karim, Karim H. 2002. Making Sense of 'Islamic Peril': Journalism as Cultural Practice. In Journalism after September 11. Edited by Barbie Zelizer and Stuart Allan. Didcot: Taylor and Francis, p. 101.

Kay, Barbara. 2014a. A Murderer's Mother. National Post, October 24.

Kay, Jonathan. 2014b. Our Video Overload: Fear is Triggered before We Know All the Facts. National Post, October 25.

Kay, Barbara. 2018. The Agony of an Attack without Explanation, and the Pain of Chaos. National Post, April 24. Available online: https:/ / nationalpost.com/opinion/barbara-kay-the-agony-of-an-attack-withoutexplanation-and-the-pain-of-chaos (accessed on 8 July 2018).

Kearns, Erin M., Allison E. Betus, and Anthony F. Lemieux. Forthcoming. Why do Some Terrorist Attacks Receive More Media Attention than Others? Justice Quarterly. [CrossRef]

Kennedy, Mark. 2014. ISIS Cruelty Demands Response, Holland Tells Packed Parliament; Also Urges Canada to Fight Climate Change. National Post, November 4. 
Kepel, Gilles. 2008. Beyond Terror and Martyrdom. Cambridge: Harvard University Press.

Koring, Paul. 2006. Canadian Catch Leads to American Anxiety. The Globe and Mail, June 5. Available online: https:/ / www.theglobeandmail.com/news/national/canadian-catch-leads-to-american-anxiety / article18164816/ (accessed on 3 July 2018).

Koring, Paul, Colin Freeze, and Doug Saunders. 2006. FBI Probes Toronto Tie to Foreign Terror Cells. The Globe and Mail, June 23. Available online: https:/ / www.theglobeandmail.com/news/world/fbi-probes-torontotie-to-foreign-terror-cells/article20414361/ (accessed on 3 July 2018).

Kowalski, Jeremy D. 2013. Framing the Toronto 18: Government Experts, Corporate Media, and the Orientalizing of the Other. In Targeted Transnationals: The State, the Media, and Arab Canadians. Edited by Jenna Hennebry and Bessma Momani. Vancouver: University of British Columbia Press, p. 129.

Kumar, Deepa. 2012. Islamophobia and the Politics of Empire. Chicago: Haymarket Books.

Kundnani, Arun. 2014. The Muslims Are Coming: Islamophobia, Extremism, and the Domestic War on Terror. New York: Verso Books.

Lamoureux, Mack. 2017. The Birth of Canada's Armed, Anti-Islamic 'Patriot' Group. Vice, June 14. Available online: https:/ / www.vice.com/en_ca/article/new9wd/the-birth-of-canadas-armed-anti-islamic-patriotgroup (accessed on 15 July 2018).

Leblanc, Daniel. 2017. Quebec City Mosque Shooter was a 'Criminal Extremist': RCMP Commissioner. The Globe and Mail, February 6. Available online: https:/ /www.theglobeandmail.com/news/politics/quebec-citymosque-shooter-was-a-criminal-extremist-rcmp-commissioner/article33920071/ (accessed on 5 July 2018).

Lewis, Seth C., and Stephen D. Reese. 2009. What is the War on Terror? Framing through the Eyes of Journalists. Journalism \& Mass Communication Quarterly 86: 85.

Mack, David. 2013. Terrorist Acts are not Society's Fault. The Globe and Mail, May 1. Available online: https:// www.theglobeandmail.com/news/politics/terrorist-acts-are-not-societys-fault/article11653597/ (accessed on 5 July 2018).

MacKinnon, Bobbi-Jean. 2014. Justin Bourque Felt 'Tired of Being Oppressed,' Report Reveals. CBC News, December 8. Available online: http://www.cbc.ca/news/canada/new-brunswick/justin-bourque-felttired-of-being-oppressed-report-reveals-1.2864465 (accessed on 11 July 2018).

Major, John. 2010. Commission of Inquiry into the Investigation of the Bombing of Air India Flight 182: A Canadian Tragedy; Ottawa: Public Works and Government Services Canada, vol. 1.

Maki, Alan. 2014. 'The Darkest Time for Islam,' Calgary-Born Muslim Doctor Says. The Globe and Mail, October 30. Available online: https:/ / www.theglobeandmail.com/news/alberta/the-darkest-time-for-islam-calgaryborn-muslim-doctor-says/article21394522/ (accessed on 3 July 2018).

Marin, Ion. 2011. The Coverage of Terrorism in the News. Geopolitics, History and International Relations 3: 254.

Martin, Patrick. 2013. How to Keep Young Muslims from Embracing Violent Movements. The Globe and Mail, April 26. Available online: https:/ /www.theglobeandmail.com/news/how-to-keep-young-muslims-fromembracing-violent-movements/article11585113/ (accessed on 3 July 2018).

Matteis, Stephanie, and Stephen Davis. 2018. Can New Vehicle Technology Prevent Attacks Like the One in Toronto? The Experts Aren't So Sure. CBC News, April 26. Available online: https://www.cbc.ca/news / canada/toronto/vehicle-technology-prevent-attacks-1.4635824 (accessed on 8 July 2018).

Mayer, Andre. 2014. Michael Zehaf-Bibeau and Martin Couture-Rouleau: How Canada Tracks Homegrown Radicals. CBC News, October 27. Available online: https:/ /www.cbc.ca/news/michael-zehaf-bibeau-andmartin-couture-rouleau-how-canada-tracks-homegrown-radicals-1.2807390 (accessed on 9 July 2018).

Meer, Nasar, Claire Dwyer, and Tariq Modood. 2010. Embodying Nationhood? Conceptions of British National Identity, Citizenship, and Gender in the 'Veil Affair'. The Sociological Review 58: 84. [CrossRef]

Mehta, Diana. 2015. Judge Orders Further Mental Assessment in 'Complicated' Via Terror Case. The Globe and Mail, July 17. Available online: https://www.theglobeandmail.com/news/national/judge-to-rule-on-crownrequest-for-fitness-assessment-for-via-rail-terror-plotter/article25544531/ (accessed on 3 July 2018).

Miller, John, and Cybele Sack. 2010. The Toronto-18 Terror Case: Trial by Media? How Newspaper Opinion Framed Canada's Biggest Terrorism Case. International Journal of Diversity in Organisations, Communities and Nations 10: 279. [CrossRef]

Miller, John, and Cybele Sack. n.d. Terrorism and Anonymous Sources: The Toronto 18 Case. Available online: http:/ / cjms.fims.uwo.ca/issues/08-01/Toronto_18.pdf (accessed on 1 July 2018). 
Mishra, Smeeta. 2007. 'Saving' Muslim Women and Fighting Muslim Men: Analysis of Representations in the New York Times. Global Media Journal 6: 1-20.

Monaghan, Jeffrey, and Adam Molnar. 2016. Radicalisation Theories, Policing Practices, and the 'Future of Terrorism?'. Critical Studies on Terrorism 9: 393-413. [CrossRef]

Montgomery, Sue. 2014. There Are No Words. National Post, June 9.

Moore, Oliver. 2018. Union Station Barriers Erected in Wake of Toronto Van Attack Stir Pushback, Debate. The Globe and Mail, April 25. Available online: https:/ / www.theglobeandmail.com/canada/article-unionstation-barriers-erected-after-toronto-van-attack-draw-pushback/ (accessed on 5 July 2018).

Moore, Kerry, Paul Mason, and Justin Lewis. 2008. Images of Islam in the UK: The Representation of British Muslims in the National Print News Media 2000-2008. Available online: http:/ / orca.cf.ac.uk/53005/1/ 08channel4-dispatches.pdf (accessed on 1 July 2018).

Morrow, Adrian. 2017. Trump Administration Cites Edmonton Attack in Call for Immigration Changes. The Globe and Mail, October 8. Available online: https://www.theglobeandmail.com/news/world/us-politics/trumpadministration-cites-edmonton-attack-in-call-for-immigration-changes/article36524833/ (accessed on 4 July 2018).

National Post. 2013. Accused Terrorist a Neighbour's Nightmare. National Post, April 26.

Naureckas, Jim. 2017. A Lesson Media Missed about the Dangers of Scapegoating. Fairness and Accuracy in Reporting, February 4. Available online: http:/ / fair.org/home/a-lesson-media-missed-about-the-dangersof-scapegoating/ (accessed on 1 July 2018).

Noor Cultural Centre. 2017. Islamophobia in Canada. Available online: https://noorculturalcentre.ca/wpcontent/uploads/2018/01/Islamophobia-in-Canada-2017.pdf (accessed on 15 July 2018).

Norris, Pippa, Montague Kern, and Marion Just. 2003. Introduction. In Framing Terrorism: The News Media, the Government and the Public. Edited by Pippa Norris, Montague Kern and Marion Just. Abingdon: Routledge.

Odartey-Wellington, Felix. 2009. Racial Profiling and Moral Panic: Operation Thread and the Al Qaeda Sleeper Cell that Never Was. Global Media Journal 2: 25.

Olwan, Dana M. 2013. Gendered Violence, Cultural Otherness, and Honour Crimes in Canadian National Logics. Canadian Journal of Sociology 38: 533.

Patel, Faiza. 2011. Rethinking Radicalization. Brennan Center for Justice at New York University School of Law. Available online: https:/ /www.brennancenter.org/sites/default/files/legacy/RethinkingRadicalization.pdf (accessed on 15 July 2018).

Payne, Kenneth. 2005. The Media as an Instrument of War. Parameters 35: 81-93.

Payton, Laura. 2014. Martin Couture-Rouleau Case Underscores Passport Seizure Dilemma. CBC News, October 21. Available online: http:/ / www.cbc.ca/news/politics/martin-couture-rouleau-case-underscores-passportseizure-dilemma-1.2807239 (accessed on 9 July 2018).

Payton, Laura. 2015. Anti-Terrorism Bill C-51 ‘Dangerous' Legislation, 100 Academics Say. CBC News, February 27. Available online: https://www.cbc.ca/news/politics/anti-terrorism-bill-c-51-dangerous-legislation100-academics-say-1.2975233 (accessed on 15 July 2018).

Peritz, Ingrid. 2014. Father of Couture-Rouleau Says Government Must Strengthen Security Laws. Globe and Mail, October 26. Available online: https:/ / www.theglobeandmail.com/news/national/father-of-couturerouleau-says-government-must-strengthen-security-laws/article21308978/links/? (accessed on 3 July 2018).

Perreaux, Les. 2018. Quebec Mosque Shooting Suspect Alexandre Bissonnette Pleads Guilty. The Globe and Mail, March 28. Available online: https://www.theglobeandmail.com/canada/article-bissonnette-pleads-guiltyto-first-degree-murder-in-quebec-shootings / (accessed on 5 July 2018).

Perreaux, Les, and Colin Freeze. 2017. Arrest Made after Hate Crime Spike Following Quebec Mosque Attack. The Globe and Mail, February 1. Available online: https:/ / www.theglobeandmail.com/news/national/policereport-rise-in-hate-crimes-after-quebec-city-mosque-attack/article33856702/ (accessed on 5 July 2018).

Perreaux, Les, Ingrid Peritz, Renata D'Aliesio, and Dakshana Bascaramurty. 2013. Terror Suspects Led Vastly Different Lives, But Allegedly Shared Same Goal. The Globe and Mail, April 23. Available online: https:/ / www.theglobeandmail.com/news/national/terror-suspects-led-vastly-different-lives-butallegedly-shared-same-goal/article11516712/ (accessed on 3 July 2018).

Perreaux, Les, Ingrid Peritz, and Robyn Doolittle. 2014a. Ottawa Shooter's Life Marked by Estrangement. The Globe and Mail, October 24. Available online: https://www.theglobeandmail.com/news/national/ ottawa-shooters-life-marked-by-estrangement/article21307292/ (accessed on 3 July 2018). 
Perreaux, Les, Patrick White, and Andrea Woo. 2014b. Drugs and Religion Key Themes in Ottawa Shooter's Troubled Life. The Globe and Mail, October 23. Available online: https:/ / www.theglobeandmail.com/news/ national/drugs-and-religion-key-themes-in-ottawa-shooters-troubled-life/article21282240/ (accessed on 3 July 2018).

Perry, Barbara, and Ryan Scrivens. 2015. Right-Wing Extremism in Canada: An Environmental Scan; Ottawa: Public Safety Canada.

Picard, Andre. 2014. We Can't Legislate Lost Souls. The Globe and Mail, October 28. Available online: https:/ /www. theglobeandmail.com/opinion/we-cant-legislate-lost-souls/article21330013/ (accessed on 5 July 2018).

Poole, Elizabeth. 2011. Change and Continuity in the Representation of British Muslims before and after 9/11: The UK Context. Global Media Journal 4: 49.

Poole, Elizabeth. 2018. Constructing 'British Values' within a Radicalisation Narrative: The Reporting of the Trojan Horse Affair. Journalism Studies 19: 376. [CrossRef]

Postmedia News. 2014. From Typical Teen to Jihadist: How Martin Couture-Rouleau Became Radicalized after Converting to Islam. National Post, November 9. Available online: https://nationalpost.com/news/canada/ from-typical-teen-to-jihadist-how-martin-couture-rouleau-became-radicalized-after-converting-to-islam (accessed on 7 July 2018).

Powell, Kimberly A. 2011. Framing Islam: An Analysis of US Media Coverage of Terrorism Since 9/11. Communication Studies 62: 90. [CrossRef]

Poynting, Scott, and Barbara Perry. 2007. Climates of Hate: Media and State Inspired Victimisation of Muslims in Canada and Australia since 9/11. Current Issues in Criminal Justice 19: 151.

Pruden, Jana G., Colin Freeze, and Kelly Cryderman. 2017a. RCMP Face Scrutiny in Wake of Edmonton Attack. The Globe and Mail, October 2. Available online: https:/ / beta.theglobeandmail.com/news/national/edmontonattack-mounties-face-scrutiny-in-wake-of-edmonton-attack/article36461018/ (accessed on 4 July 2018).

Pruden, Jana G., Marty Klinkenberg, Karen Howlett, and Morgan Bocknek. 2017b. Edmonton Attack Suspect Facing Terrorism Charges Was Investigated by RCMP in 2015. The Globe and Mail, October 1. Available online: https:/ / www.theglobeandmail.com/news/national/edmonton-attack-terrorism-truckisis/article36449925/ (accessed on 4 July 2018).

Public Safety Canada. 2013. 2013 Public Report on the Terrorist Threat to Canada. Available online: https: / / www.publicsafety.gc.ca/cnt/rsrcs/pblctns/trrrst-thrt-cnd/index-en.aspx (accessed on 15 July 2018).

Pugliese, David. 2018. Motives Behind Using Vehicles in Attacks Vary. National Post, April 24.

Razack, Sherene. 2007. Casting Out: The Eviction of Muslims from Western Law and Politics. Toronto: University of Toronto Press.

Rhodes, Blair. 2015. Why the Halifax Shooting Plot Charge Isn't Considered a 'Terrorist Event.' CBC News, February 16. Available online: https:/ / www.cbc.ca/news/canada/nova-scotia/why-halifax-shooting-plotcharge-isn-t-considered-terrorist-event-1.2958628 (accessed on 11 July 2018).

Roach, Kent. 2018. Why the Quebec City Mosque Shooting Was Terrorism. The Globe and Mail, April 19. Available online: https: / www.theglobeandmail.com/opinion/article-why-the-quebec-city-mosque-shooting-wasterrorism/ (accessed on 5 July 2018).

Sabry, Omar. 2015. Torture of Afghan Detainees: Canada's Alleged Complicity and the Need for a Public Inquiry. Canadian Centre for Policy Alternatives and Rideau Institute. Available online: https:/ / www.policyalternatives.ca/ sites/default/files/uploads/publications/National\%20Office/2015/09/Torture_of_Afghan_Detainees.pdf (accessed on 15 July 2018).

Saunders, Doug. 2014. When Troubled Young Men Turn to Terror, Is It Ideology or Pathology? The Globe and Mail, October 24. Available online: https:/ / www.theglobeandmail.com/news/national/lone-wolf-ideology-orpathology/article21293910/ (accessed on 5 July 2018).

Selley, Chris. 2015. Why Such Haste on Syrian Refugees? National Post, November 18.

Shier, Allie, and Eran Shor. 2016. Shades of Foreign Evil: 'Honour Killings' and 'Family Murders' in the Canadian Press. Violence Against Women 22: 1163. [CrossRef] [PubMed]

Silcoff, Sean. 2014. Tories to Table Expanded Security Bill. The Globe and Mail, October 17. Available online: https:// www.theglobeandmail.com/news/politics/tories-to-table-expanded-security-bill/article21311502/ (accessed on 3 July 2018). 
Simpson, Jeffrey. 2014. The End of Innocence? Only for the Innocent. The Globe and Mail, October 23. Available online: https:/ / www.theglobeandmail.com/opinion/the-end-of-innocence-only-for-the-innocent/ article21251726/ (accessed on 3 July 2018).

Simpson, Jeffrey. 2015. Put Jihadism in its Place: One Threat Among Many. The Globe and Mail, June 13. Available online: https:/ / www.theglobeandmail.com/opinion/put-jihad-in-its-place-one-threat-amongmany / article23427570/ (accessed on 3 July 2018).

Smolash, Wendy Naava. 2009. Mark of Cain(ada): Racialized Security Discourse in Canada's National Newspapers. University of Toronto Quarterly 78: 745. [CrossRef]

Soupcoff, Marni. 2017. Grim Reminders; Las Vegas and Edmonton Attacks Reveal Futility of Obsessing about 'Terrorism'. National Post, October 5.

Southern Poverty Law Center. 2017. Male Supremacy. Available online: https:/ /www.splcenter.org/fightinghate/extremist-files/ideology/male-supremacy (accessed on 15 July 2018).

Stampnitzky, Lisa. 2013. Disciplining Terror: How Experts Invented 'Terrorism'. Cambridge: Cambridge University Press. Steuter, Erin, and Deborah Wills. 2009a. At War with Metaphor: Media, Propaganda, ad Racism in the War on Terror. New York: Lexington Books.

Steuter, Erin, and Deborah Wills. 2009b. Discourses of Dehumanization: Enemy Construction and Canadian Media Complicity in the Framing of the War on Terror. Global Media Journal 2: 7-24.

Swain, Diana. 2017. Mass Murder or Terrorism? Who Decides What to Call It? CBC News, October 7. Available online: http:/ / www.cbc.ca/news/world/mass-murder-vs-terrorism-1.4344766 (accessed on 10 July 2018).

Taber, Jane. 2014. 'I Am Sorry' for RCMP Shootings, Bourque Tells Sentencing Hearing. The Globe and Mail, October 28. Available online: https:/ /www.theglobeandmail.com/news/national/justin-bourquesentencing-hearing/article21348506/ (accessed on 5 July 2018).

The Globe and Mail. 2015. A Timeline of Deadly Attacks in Western Nations. The Globe and Mail, February 18. Available online: https:/ / www.theglobeandmail.com/news/world/a-timeline-of-deadlyattacks-in-western-nations-since-2011/article23040834/ (accessed on 3 July 2018).

Thobani, Sunera. 2003. War and the Politics of Truth-Making in Canada. Qualitative Studies in Education 16: 399. [CrossRef]

Thomson, Aly. 2017. Front-Line Officers Felt 'Outgunned' before Moncton Shootings, Trial Hears. The Globe and Mail, April 27. Available online: https:/ / www.theglobeandmail.com/news/national/front-line-officersfelt-outgunned-moncton-shootings-trial-hears/article34829878/ (accessed on 5 July 2018).

Tutton, Michael, and Tim Callanan. 2015. Man in Alleged Halifax Plot Never Spoke of Guns, Says Friend. The Globe and Mail, February 15. Available online: https:/ / www.theglobeandmail.com/news/national/manin-alleged-halifax-plot-never-spoke-of-guns-says-friend/article23008682/ (accessed on 5 July 2018).

United Nations. 2016. Countering Violent Extremism a 'Perfect Excuse' to Control the Media-UN Expert. Available online: https:/ / www.ohchr.org/EN/newsEvents/Pages/DisplayNews.aspx?NewsID=19916\& LangID=E (accessed on 15 July 2018).

Vanta, Maria. 2015. Bourque Probe Calls for More RCMP Carbines. National Post, March 28.

Wagstaff, Robert. 2013. The War Paradigm Versus the Criminal Law in the United States. In Terror Detentions and the Rule of Law: US and UK Perspectives. Oxford: Oxford University Press.

Wark, Wesley. 2006. Terror's Deadly Race. The Globe and Mail. August 12. Available online: https://www. theglobeandmail.com/opinion/terrors-deadly-race/article731295/ (accessed on 3 July 2018).

Warnica, Richard. 2015. If Esseghaier is Insane, Does it Matter? Psychiatric Report Raises Questions. National Post, August 29.

Warnica, Richard. 2017. Fanatacism Confused? Presumed Jailed Terrorist Says He's Insance. National Post, July 29.

Watters, Haydn. 2015. RCMP Release Unseen Video from Zehaf-Bibeau's Manifesto. CBC News, May 29. Available online: http:/ / www.cbc.ca/news / politics /rcmp-release-unseen-video-from-zehaf-bibeau-s-manifesto-1. 3092462 (accessed on 9 July 2018).

Wente, Margaret. 2014. What Do We Do About the Islamic State Fanboys? The Globe and Mail, May 12. Available online: https:/ / www.theglobeandmail.com/opinion/what-do-we-do-about-the-islamic-state-fanboys / article21294146/ (accessed on 3 July 2018).

Wente, Margaret. 2018. Is Misogyny to Blame for the Mayhem in Toronto? The Globe and Mail, April 26. Available online: https: / www.theglobeandmail.com/opinion/article-is-misogyny-to-blame-for-the-mayhem-intoronto/ (accessed on 5 July 2018). 
Wingrove, Josh. 2014a. Ottawa Shooter Referred to Allah in Video, RCMP Says. The Globe and Mail, October 27. Available online: https://www.theglobeandmail.com/news/national/ottawa-shooter-praised-allah-invideo-rcmp-says/article21327760/ (accessed on 3 July 2018).

Wingrove, Josh. 2014b. How Canada's Terror Laws Could Change. The Globe and Mail, October 31. Available online: https://www.theglobeandmail.com/news/politics/how-canadas-terror-laws-couldchange/article21418251/ (accessed on 3 July 2018).

Wingrove, Josh, and Jane Taber. 2014. Conservatives Weigh New Powers for Police after Ottawa Shooting. The Globe and Mail, October 24. Available online: https://www.theglobeandmail.com/news/politics/ conservatives-weigh-what-new-powers-to-give-police-after-ottawa-shooting/article21296410/ (accessed on 3 July 2018).

Woo, Andrea. 2014. Burnaby Mosque in Spotlight after Ottawa Attack. The Globe and Mail, October 24. Available online: https:/ / www.theglobeandmail.com/news/british-columbia/burnaby-mosque-in-spotlight-afterottawa-attack/article21306810/ (accessed on 3 July 2018).

Woods, Joshua. 2011. Framing Terror: An Experimental Framing Effects Study of the Perceived Threat of Terrorism. Critical Studies on Terrorism 4: 199. [CrossRef]

(C) 2018 by the author. Licensee MDPI, Basel, Switzerland. This article is an open access article distributed under the terms and conditions of the Creative Commons Attribution (CC BY) license (http:/ / creativecommons.org/licenses/by/4.0/). 